\title{
A model to prioritise Sustainable Urban Regeneration in vulnerable areas using SWOT and CAME methodologies
}

\author{
${ }^{* 1}$ María José Ruá; ${ }^{1}$ Patricia Huedo; ${ }^{2}$ Manuel Cabeza; ${ }^{2}$ Beatriz Saez; ${ }^{3}$ Raquel Agost-Felip \\ ${ }^{1}$ Universitat Jaume I. Department of Mechanical Engineering and Construction, \\ ${ }^{2}$ Universitat Jaume I. Department of Industrial Systems and Design \\ ${ }^{3}$ Universitat Jaume I, Departament of Developmental, Educational and Social Psychology and Methodology. \\ *Correspondent author: rua@uji.es
}

\begin{abstract}
This work proposes a model for decision-making support to help Administrations to undertake urban regeneration and refurbishment by prioritising vulnerable neighbourhoods and buildings. In order to suggest regeneration measures in vulnerable areas, the SWOT analysis is proposed for identifying determining factors of vulnerability. This permits information to be arranged into categories to obtain a multiperspective diagnosis. The complementary CAME methodology completes the above analysis to Correct Weaknesses, Adapt to Threats, Maintain existent Strengths and Explore detected Opportunities. The combination of these methodologies, scarcely used before in urban regeneration, has proven useful for suggesting general urban regeneration guidelines in complex contexts, which urban environments are, where physico-social conditions clearly interrelate. Thus specific Challenges can be suggested and later materialised through specific urban Lines of Action adapted to specific needs in a studied area. When considering the buildings in an area, they present distinct ages, typologies, and structural and constructive features, so refurbishment solutions cannot be standardised. This work's proposal is to intervene in social housing of municipal property that is representative of vulnerable buildings. The results are presented on practical datasheets, where regeneration and refurbishment solutions are summarised and economically estimated. This general methodology can be replicated in different contexts by adjusting specific features of areas. The city of Castellón was selected as an empirical case to validate the proposed model.
\end{abstract}

\section{Keywords}

Urban regeneration; vulnerable area; social housing; SWOT analysis; CAME analysis; decision-making. 


\section{Introduction}

The prioritisation of certain urban areas for urban regeneration used to be a key point in decision making due to budget constraints. Latest urbanism trends now intervene in the existing city and prioritise interventions in vulnerable areas, which is aligned with sustainable development (Zheng et al., 2014; Balaras et al., 2018; Lee, 2014). Indicators to detect the worse social conditions are crucial for identifying deprivation and distress in some areas rather than in others (Sánchez-Cantalejo et al., 2008; Conway and Konvitz, 2000).

In this work, we propose a model to perform urban regeneration in vulnerable areas to help local administrations in their decision making. By doing so, the city scale reduces and shines the spotlight on vulnerable areas. It permits a more detailed diagnosis and made-to-measure proposals for the weakest areas. At this point, the implementation of the SWOT matrix (Strengths, Weaknesses, Opportunities and Threats) is proposed to diagnose the area. Then a complementary CAME matrix can be applied to Correct Weaknesses, Adapt to Threats, Maintain existent Strengths and Explore detected Opportunities by establish general guidelines to undertake urban regeneration. These relatively simple methodologies can be a valuable tool that permits multidisciplinary information to be arranged from a plurality of perspectives when they need to be considered, which occurs in urban contexts. However, they must be based on a well-founded and comprehensive analysis of the area. The proposed guidelines can be the starting point to suggest concrete Lines of Action that adapt to the area.

Then we propose descending to the building scale as they play a key role when considering an urban area, where different typologies and distinct constructive qualities of buildings and maintenance status usually coexist. Focus should be placed on those buildings with most vulnerability, which should be prioritised for refurbishment. Selecting particular vulnerable buildings permits a more detailed approach to be adapted to specific conditions to make optimal refurbishment proposals by allocating funds where they are most needed. Considering the vulnerability focus, social housing of public property could be selected to thus reach the building scale. This selection is twofold: on the one hand, the aim of social housing is for it to be occupied by vulnerable populations. On the other hand, they are also seen as an opportunity because they group numerous dwellings in a single building block, whose public property ensures the participation of local authorities in their maintenance and refurbishment. 
This paper is structured as follows:

Firstly, the background introduces the urban regeneration concept into the sustainable development context and explains how policies in the European Union work towards this end. Secondly, the methodology section presents the proposal of a general model that considers three scales: the city, the neighbourhood and the building scale. On the first scale, the city's main features and its urban development should be analysed to contextualise its current urban state. The regulatory framework on urban and building scales, and at different times, is crucial to understand how a city has been shaped. The neighbourhood and building scale are selected by considering their vulnerability and by assuming that they should be prioritised when urban regeneration is undertaken. The model proposes to perform a SWOT matrix to diagnosis the area and to later apply a CAME matrix for different categories. They permit specific Challenges to be set out that need to be materialised by proposing specific Lines of Action that adapt to the considered area. Finally, the most vulnerable buildings are selected to present specific refurbishment measures.

The city of Castellón (Valencian Community, east Spain) is presented as an empirical case to validate the proposed model. A vulnerable area is selected according to two main sources. On the one hand, the complementary report Study and Proposal of Areas for Refurbishment, Regeneration and Urban Renewal (ARRU) for the development of the Land-Use Plan, (García et al., 2017). The definition of ARRU is consistent with the Law 5/2014, 25 July, Territorial Planning, Urban Planning and Landscape for the Valencian Community and ammends Law 1/2019, 5 February (Ley 5/2014, de 25 de julio, de la Generalitat, de Ordenación del Territorio, Urbanismo y Paisaje, y las modificaciones de la Ley 1/2019, de 5 de febrero, de la Comunitat Valenciana, LOTUP). ARRU constitute priority areas to allocate public funds for urban regeneration (Article 72, LOTUP). Nationally, it is also aligned with State Plan 2013-2016 for the promotion of housing rental, building rehabilitation, and regeneration and renovation urban (extended till 2017 and continued by Royal Decree 106/2018 for the 2018-2021 period), published in Royal Decree 233/13. This plan aims to finance the joint implementation of rehabilitation works in buildings and homes, urbanisation or redevelopment of public spaces and, wherever appropriate, building to replace demolished buildings. It intends to improve residential fabrics and recover sets of historic and urban centres, degraded neighbourhoods and rural centres. To implement such a plan, there are some starting requirements: firstly, the area must be 
declared by an agreement reached with the Administration; it must be geographically continuous or discontinuous; it has to be composed of at least 100 dwellings. Secondly, at least $60 \%$ of the buildable area must be used for residential use (habitual residence). Besides, building refurbishment must be performed according to the Owners Association's agreement, which needs to prepare the "Building Evaluation Report" (IEE, standing for Informe de Evaluación del Edificio, in Spanish). This is a mandatory report to be issued in buildings standing for more than 50 years, where conservation, accessibility and energy performance must be evaluated by a competent professional to diagnose the building's state in order to suggest refurbishment solutions. The proposal of the delimitation of vulnerable areas corresponds to the City/Town Council, which should initiate the procedures to request the declaration of ARRU to the Regional Government (which is the Generalitat Valenciana in the Valencian Community) which, together with the Ministry of Development, will declare the proposed area as ARRU so that it can benefit from funds.

On the other hand, a previous study entitled "A simplified model to assess vulnerable areas for urban regeneration”, published in the Sustainable Cities and Society Journal (2019),46, 101440 (Ruá et al, 2019), explains the definition of the ARRU in the city in further detail. In that work, the neighbourhood scale is defined according to the definition of ARRU. From these previous references, we propose applying the SWOT and CAME methodologies on the neighbourhood scale.

At the same time, an analysis of the public social housing stock in this city was done by assuming that they are vulnerable buildings. Buildings are classified according to their typology and year of construction, and are geolocated in the ARRU. The neighbourhood ARRU01, named Castalia-La Guinea, with the most publicowned social housing in the city, was selected as a case study. Its features are briefly described and analysed to set out some proposals on the urban scale. On the building scale, the selection of a representative block of social housing is followed by its analysis and the proposal of specific measures. The visit to the site and the original plans are studied, and a BIM tool is implemented for graphical representation purposes.

Finally, the last section concludes and introduces discussion into the undertaken work. 


\section{Background}

Sustainable Development Goals (SDG) of the United Nations' Agenda 2030, include urban environment with the 11th SDG for sustainable cities and communities, which aims "to make cities inclusive, safe, resilient and sustainable". The New Urban Agenda (UN, 2017) endorses this goal by presenting urbanism as a powerful tool for sustainable development.

In this regard, Cohen (2013) reviewed the scientific literature on urban sustainability assessment. He found that it could be better aligned with common sustainability principles and that unified framing was generally lacking. From this review, he proposed a generic framework to structure urban sustainability assessments by identifying 29 categories, such as building, education, land use, etc. This could be useful for assigning indicators to measure the progress made towards sustainable urban development. However, the assessment should be based on identifying actionable goals for each category and their organisation around a framework of integrative principles.

When it comes to existent urban environment, urban regeneration according to sustainability criteria is a challenging goal. Zheng et al. (2014), reviewed 81 journal papers on sustainable urban renewal for the 19902012 period by focusing on the planning subsystem and the social subsystem of urban renewal in sustainability evaluation terms. The authors pointed out that the terms urban renewal, urban regeneration, urban redevelopment and urban rehabilitation had similar meanings, which differed in scale terms. Besides, urban renewal could be used interchangeably with urban regeneration to improve the physical, socialeconomic and ecological aspects of urban areas. On a smaller scale, urban development could be applied to any new construction on a site with pre-existing uses, and urban rehabilitation was applied to restore a building to good condition. Even when considering a smaller scale, a bottom-up strategic urbanism could promote the local potential to solve site-specific issues through the so-called urban acupuncture, which involves the idea of conducting sporadic interventions in strategic places as the city is considered to be interconnected systems. This expression has been used by authors like Jaime Lerner (Lerner, 2007) or De Sola Morales (2008), who claim that this approach is based on stimulating urbanism through minimum interventions to achieve the maximum effect. This strategy is effectively applied by contemporary 
architecture in the public realm, and a growing number of projects currently adopt this approach in collective areas to seek to benefit for the entire city as it is not only a collection of buildings, but a dynamic and relational space with social life. The same idea was shared by Enia and Martella (2019), who pointed out that, although some places demand major changes, others require only a few modifications if they are welldesigned, which also allows beneficial effects on surroundings to be achieved. Some examples of this approach are found in the Eco-Acupuncture program, developed in metropolitan Melbourne, which focuses on many minor interventions in an existing urban precinct that could shift the community's ideas of what is permissible, desirable and possible, and provide transformation points for a new line of development towards a resilient low-carbon future (Ryan, 2013). Another project in the old fishing harbour of Tallinn, Estonia, explored the role of small-scale interventions in enriching the environment and changing the behaviour of green space users by implementing field observations and behaviour mapping to compare the spatial pattern of users before and after interventions (Unt and Bell, 2014).

Focusing on the urban regeneration scale seeks to address policies that solve a place's problems in all its multiple dimensions, which is place-focused by nature (De Maghalães, 2015). This requires purposive action through policy and direct interventions as market forces do not suffice to ensure the transformation. Across countries, different policy and institutional contexts have also shaped variations in urban regeneration policy objectives. Current regeneration interventions should go beyond physical redevelopment by addressing them towards the stimulation of economic growth, reduced social inequality and increased social cohesion. This is the goal of the Integrated Urban Regeneration, as presented by Alpopi and Manole (2013), who provided some examples of interventions made in European countries from the 2010 Declaration of Toledo of the European Union. Coach et al. (2011) explored 30 years of urban regeneration in three European countries, the United Kingdom, France and Germany, and found that it is hard to identify a 'European model' for a successful urban regeneration policy. The differences in population density and urbanisation patterns in each country constitute an influential setting for developing a regeneration policy, although these authors found some underlying principles linked with the common concern to ensure that certain social groups in the population are not excluded. This idea was supported by Natividade-Jesus et al. (2019), who presented an experience from a large-scale project to regenerate downtown Coimbra, where the University of Coimbra was 
engaged with the City Council to plan regeneration action. Barosio et al. (2016) conducted a literature review on urban regeneration to reveal that interventions have gradually shifted from being place-oriented to being people-oriented. They presented a paradigmatic case, the city of Turin, from 1995 to 2015 to show the existence of three generations of neighbourhood transformations. The first generation involved mainly physical improvement, while the second was characterised by social and economic support. The third generation presented an integrated approach.

In the European Union, urban issues have been included in the Agenda since the 1990s. The implementation of URBAN (1994-1999), continued by URBAN II (2000-2007), resulted in a relevant advancement made in the urban regeneration field. During the 2007-2013 period, the urban dimension of the EU policy was mainstreamed in the Operational Programmes of Member States, which gave them the chance to implement integrated urban regeneration initiatives into their cities by putting the "URBAN method" into practice. The comparison of countries revealed that those with widespread territorial decentralisation presented more disperse urban planning decisions due to the diversity of regional or local stakeholders, than those countries with administrative centralisation.

The 2010 "Integrated Urban Regeneration in Europe" report, conducted by a group of experts at the Institute of Urban Studies of Valladolid University (Alvarez and Roch, 2010), was issued in response to the request of the Directorate General of Land and Urban Policies of the Spanish Ministry of Housing as part of the Spanish Presidency of the European Union Council. It collected information from a questionnaire with 18 questions, entitled "Questions on integrated urban regeneration polices", which was sent to all 27 EU Member States, to the three candidate states (in 2010), and also to Norway and Switzerland. One of the main conclusions drawn was that the most frequent regeneration operations can be grouped around two main types: those acting in central areas, such as historic districts or neighbourhoods of traditional cities; those which coordinate various programmes and policies of social and housing improvements in the so-called "vulnerable" or "deprived" areas. One of the main conclusions taken from the survey was most interventions dealt with specific questions and problems from very particular domains and that, far from global approaches to cities, a wide variety of intervention forms, funding mechanisms, regulation tools and levels and competences fields appeared to be 
involved in urban regeneration processes of. They mostly focused on physical intervention (on buildings, housing, public spaces and/or infrastructure), and only a few centred on actions from a social perspective.

In Spain, the "Urban Method" was implemented through the so-called Iniciativa Urbana. According to De Gregorio-Hurtado (2012), this new initiative did not make any relevant progress compared to the previous one regarding the development of integrated, collaborative and innovative urban regeneration strategies. The next period was 2014-2020, when European Regional Development Fund (ERDF) funding to reduce economic, environmental and social problems in urban areas was implemented in Spain through Order HAP/2427/2015, 13rd November, which approved the first call to select strategies of Sustainable Integrated Urban Development (Estrategias de Desarrollo Urbano Sostenible e Integrado, EDUSI). The second and third calls were Order HAP/1610/2016, 6th October and Order HFP/888/2017, 19th September, respectively. Those strategies were intended for communities or group of communities with more than 20,000 inhabitants. In order to address problems on a smaller scale, e.g. the neighbourhood scale, financial aid was regulated specifically by targeting these areas through the so-called "Urban Renewal and Regeneration Areas" (ARRU) "within State Housing Plans, focusing primarily on deprived neighbourhoods, considering social, economic and environmental perspectives". Since the 1980s, 3-year State Housing Plans have played a crucial role in defining housing policies in Spain by establishing the State's housing policy priorities. The multilevel governance structure of housing policies in Spain means that regional governments implement State Plans, but also maintain the main powers to develop their own policies in this domain. Plan 2013-16 was intended to promote housing production, the occupation of new land, the planning of city growth, and the commitment to property-ownership as the main way to access housing. A new State Housing Plan was approved in Spain for the 2018-2021 period to support urban regeneration through not only urban and rural regeneration, but also through the rehabilitation of the housing stock by improving energy efficiency, safety and building accessibility (Arriba and Rodríguez, 2018).

\section{Methodology}

Figure 1 presents the flow chart with the main steps followed in this work. 


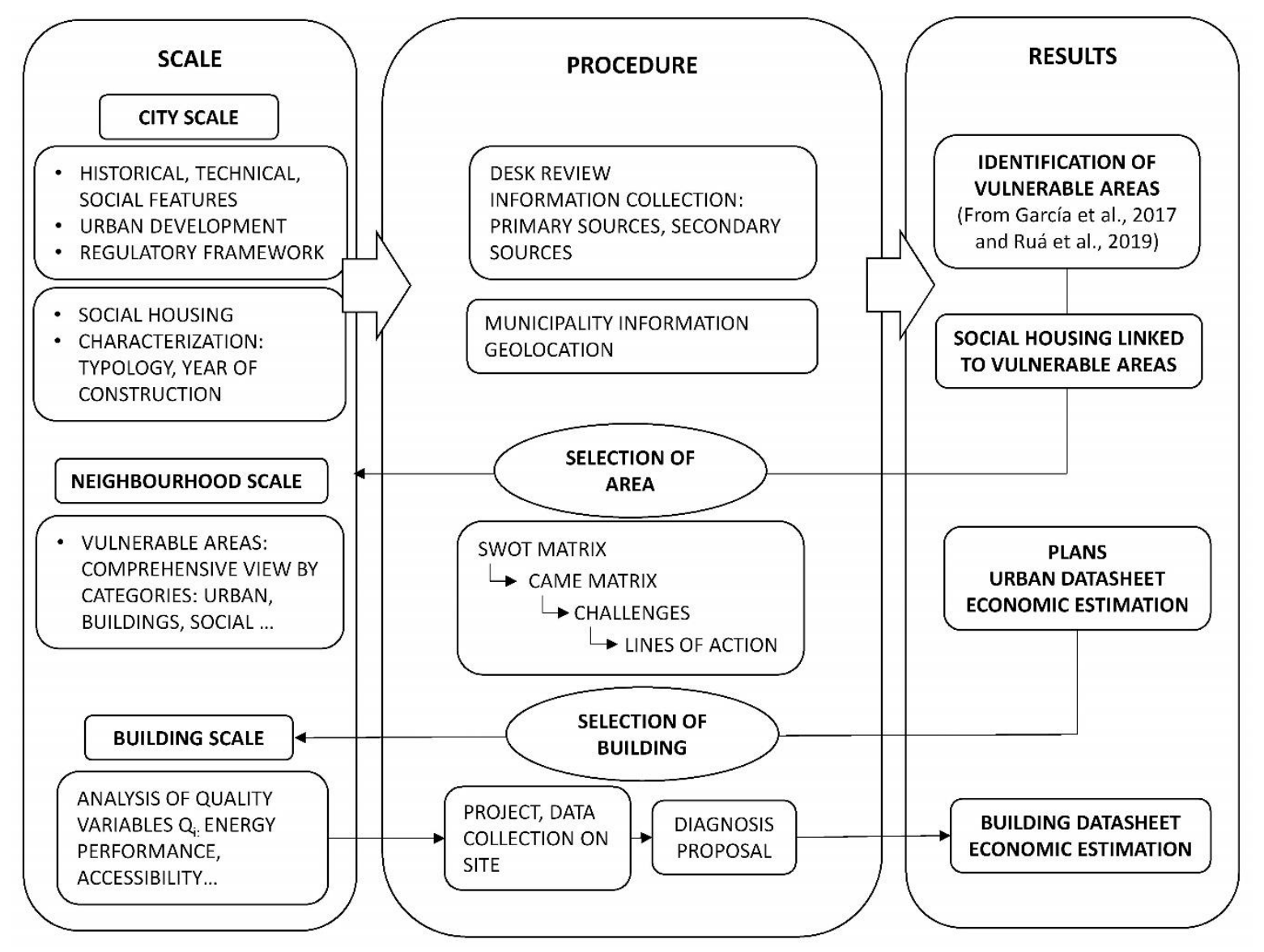

Figure 1. Proposed of model

On the city scale, a rigorous study of urban planning evolution and building regulations helps to understand the shortcomings of the physical environment.

The prioritisation of vulnerable areas for intervention permits descent to the neighbourhood scale where four steps are proposed, as presented in Figure 1. The first step consisted in a general diagnosis of vulnerable, performed by a SWOT matrix. In the SWOT Analysis, the strong and weak aspects of an organisation are identified by examining the elements in its environment, while environmental opportunities and threats are determined by examining the elements outside its environment (Gürel et al 2017). This methodology has been widely used in business and management (Lee and Sai On Ko, 2000; Pickton and Wrigth, 1998; Salar and Salar, 2014), but has been used less often to analyse data for urban purposes. For example, Soliman (2012) applied SWOT to understand the informal settlements of housing development in Egyptian cities. Warren et 
al. (2015) used it to arrange data to develop a sustainable transport system in La Havana. Mosanenzadeh et al, 2017a, 2017b, included SWOT in their research about smart energy cities; Naterer et al., (2018) analysed its application in some Slovenian cities for urban development purposes. Other authors have used SWOT for regeneration of historic centres where cultural heritage must be considered. Doretli et al., 2004 proposed revitalisation strategies in historic urban quarters in Cyprus. Ferreti and Gandino (2018) used it to support the planning and management of the vineyard landscape of Langhe, Roero and Monferrato in Italy, a new World Heritage site. Crescendo et al. (2018) performed a SWOT analysis to regenerate the historic centre of Trieste (Italy). However, the methodology has scarcely been used for the urban regeneration of vulnerable areas. For example, Doo-Hwan and Byung-Ju (2015) suggested using the SWOT analysis combined with IT technologies such as GIS, 3D/4D and Building Information Modelling (BIM). Mehmet and Yakup (2016) proposed employing this methodology to solve inner city deprived areas with socio-economic problems, in addition to its physical conditions, in a Turkish neighbourhood. The Valencian Government (Generalitat Valenciana) recommends the authorities of municipalities in the Valencian Community to apply a SWOT analysis to propose urban regeneration strategies with the document Directrices para el desarrollo de Estrategias de Regeneración Urbana para municipios de la Comunitat Valenciana (Guidelines to Develop Urban Regeneration Strategies in the Valencian Community, ERU, 2018).

In this work, the implementation of the SWOT analysis is proposed to arrange information on the neighbourhood scale to obtain a structured diagnosis. Some matrices can be built up for distinct categories or perspectives. Strengths, Weaknesses, Opportunities and Threats are represented by $S_{i j}{ }^{n}, W_{i j}{ }^{n}, O_{i j}{ }^{n}$ and $T_{i j}{ }^{n}$, respectively, where superindex $n$ identifies the vulnerable area, if some are analysed, subindex $i$ represents the considered category or point of view and subindex $j$ denotes the ordinal number. The second suggested step consists in building up a CAME matrix, inferred from diagnosing the SWOT matrix. The CAME analysis is a strategic planning tool that supplements the SWOT analysis and permits guidelines to be established on the aspects found in the previous diagnoses. It has been used in business, but we found no reference of using this tool in urban regeneration. As in the SWOT matrix, the general strategies are drawn up the $\mathrm{C}_{\mathrm{ij}}{ }^{\mathrm{n}}, \mathrm{A}_{\mathrm{ij}}{ }^{\mathrm{n}}, \mathrm{M}_{\mathrm{ij}} \mathrm{j}^{\mathrm{n}}$ and $\mathrm{E}_{\mathrm{ij}}^{\mathrm{n}}$ in the CAME matrix.

The CAME matrix, in step 2, permits setting out specific Challenges for each category. Challenges are represented by $\mathrm{C}_{\mathrm{ij}}{ }^{\mathrm{n}}$, which form the step 3 . Once Challenges have been set up, they have to be materialised. 
This is done by some Lines of Action, $\mathrm{LA}_{\mathrm{ij}}{ }^{\mathrm{n}}$, where, again, $j$ is the ordinal number of Lines of Action in each category $i$ in urban area $n$. They can be summarised later using datasheets, where an economic estimation is added to provide an order of magnitude of the cost. Finally in step four, they can be materialised in precise Lines of Action.

On a lower scale, the selection of the most vulnerable buildings requires an in depth analysis of the building stock in the area. Buildings are characterised by considering their typology (single family, multi-family, etc.), year of construction and constructive characteristics. The diagnosis of the selected buildings is based on some quality variables $\mathrm{Q}_{\mathrm{i}}$ such as energy performance and accessibility. The available documentation, projects and plans, and a visit to the building site, are necessary to collect the required information. The current building regulations applied to the analysed variables are analysed to determine their degree of obsolescence and to make refurbishment proposals. On this scale, the economic cost can be more accurately estimated, depending on the optimum refurbishment solution adapted to the specific needs of the buildings.

\section{Empirical study}

\subsection{The city scale}

Castellón is a medium-sized coastal city with about 170,000 inhabitants, located in east Spain. It was conceived as a city in the 13th century, when small groups of detached and spread Muslim farmsteads formed the Middle Age village. The city was later surrounded by a defensive wall, which remained until the beginning of the 19th century, where the historic city centre now stands (Esteve-Comes, 2012). In 1837, the city built a new rhomboid-shaped defensive wall that included the suburbs and many gaps. In 1885 , the walls were completely demolished and the peripheral city areas were included in the city. The first Land-Use Plan (Plan General de Ordenación Urbana, PGOU, in Spanish) was drawn up in 1925. It considered three urban areas: inner area, first expansion area and new expansion area. However, this plan failed because the Spanish Civil War began. When this war ended in 1939, a new plan was passed, which included new squares and avenues that shaped the city. The next PGOU was passed in 1963, in accordance with the National Land Law of 1956, but it was not effective. Due to the socio-economic circumstances and the immigration of the city's rural population, the demand for new dwellings was growing. This led to compact growth, and also a disproportionate increase in building height that increased building density. The urban layout in the 1980s and 
1990s underwent major transformations. The PGOU further structured the already structured territory, with big new urban plans for residential use, and single-family or multi-family houses in the areas surrounding the city. Recently, a new PGOU has been issued in which, according to new urban regulations (LOTUP), ARRU are defined. Figure 2 shows the urban city development when considering different periods.

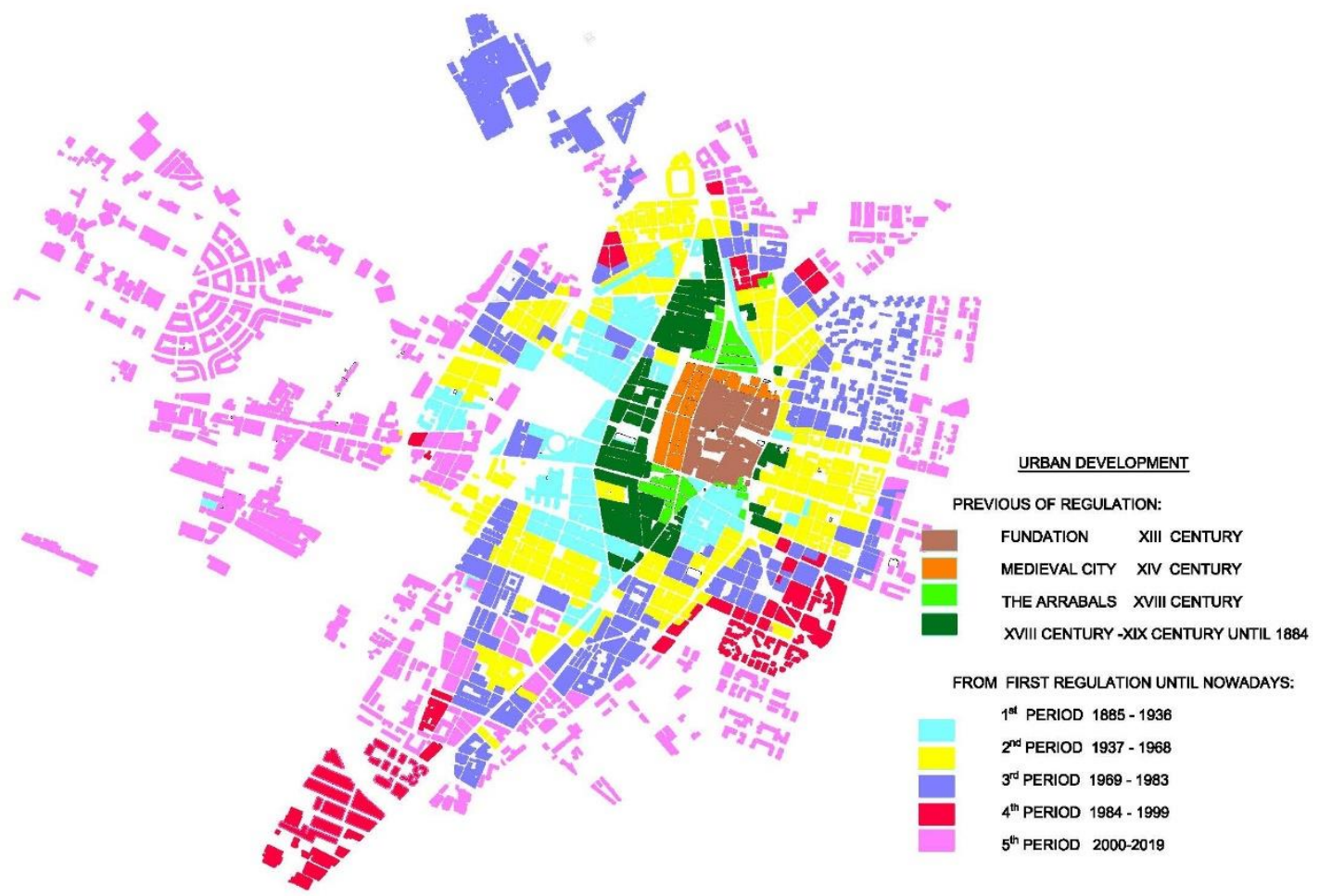

Figure 2. Development of the urban fabric in Castellón

There is a direct link between urban development and the characteristics of building typologies. Table 1 summarises the urban development periods linked to the urban plans and the buildings regulations that were in force in Castellón from the late $19^{\text {th }}$ century to the present time. It presents the development of building regulations to illustrate variation in requirements and quality standards. 
Table 1. Urban Development based on Land Plans and Buildings Regulations in Castellón.

\begin{tabular}{|c|c|c|c|}
\hline & \multicolumn{2}{|c|}{ URBAN DEVELOPMENT - LAND PLANS } & \multirow{2}{*}{$\begin{array}{l}\text { BUILDING REGULATIONS } \\
\text { Date/Content/Apply To }\end{array}$} \\
\hline & Year & Content/ Typology & \\
\hline \multirow[b]{3}{*}{ 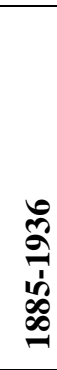 } & 1885 & $\begin{array}{l}\text { Expansion in orthogonal grid and Southeast } \\
\text { periphery / One bay terraced house. Ground } \\
\text { floor for animals }+1 \text { floor }\end{array}$ & \\
\hline & 1914 & $\begin{array}{l}\text { Asphalted streets and electric lighting / One } \\
\text { bay terraced house. Ground }+1-2 \text { floors (f) }\end{array}$ & $\begin{array}{l}\text { 12-06-1911 / Minimum hygiene requirements } \\
\text { / Housing for the working class }\end{array}$ \\
\hline & 1925 & $\begin{array}{l}3 \text { zones: Historic centre (Hc), Expansion zone } \\
\text { (E) and Garden city (G) / Hc: Terraced house. } \\
\text { Ground }+1-2 \text { floor. E: Up to } 3 \text { floors. G: } \\
\text { Detached single-family houses. }\end{array}$ & $\begin{array}{l}\text { 29-07-1925 / Minimum hygiene requirements } \\
\text { / Housing for the middle class }\end{array}$ \\
\hline \multirow[b]{6}{*}{$\frac{\mathscr{2}}{2}$} & & $\begin{array}{l}\text { Regeneration of urban fabric. Opening of } \\
\text { streets and squares. Messy growth / Terraced }\end{array}$ & $\begin{array}{l}\text { 08-09-1939 / Regulations on Limited Income } \\
\text { / Limited-Income Housing }\end{array}$ \\
\hline & 1939 & $\begin{array}{l}\text { house. Ground }+3-4 \\
\text { Compact city, few interior } \\
\text { Detached houses with garden. }\end{array}$ & \\
\hline & 1945 & $\begin{array}{l}\text { Groups of social housing / Linear blocks with } \\
\text { central garden / periphery. Ground floor }+3-4 \\
\text { floors, with no lift. }\end{array}$ & $\begin{array}{l}\text { 01-03-1944 / Basic Hygiene Conditions for } \\
\text { Housing / All housing }\end{array}$ \\
\hline & \multirow[t]{3}{*}{1955} & $\begin{array}{l}3 \text { zones and } 11 \text { subzones: Hc ( } 3 \text { subzones), E } \\
\text { ( } 7 \text { subzones, and Garden city ( } 1 \text { subzone) / } \\
\text { Linear block adjacent to U-shaped streets, } \\
\text { without courtyards, ground }+4 \text { floors and } 10\end{array}$ & $\begin{array}{l}\text { 29-05-1954 / Mandatory concrete roofs and air } \\
\text { chambers / Low-income housing }{ }^{2} \\
12-07-1955 \text { and 12-05-1956 / Urban and } \\
\text { constructive aspects / All housing }\end{array}$ \\
\hline & & floors towers. Detached linear block & 16-05-1965 / Technical Ordinances and \\
\hline & & $\begin{array}{l}\text { surrounded by green areas. } 2 \text { dwellings/floor. } \\
\text { Ground }+3 \text { floors. Isolated towers and } \\
\text { detached linear block ground }+3 \text { floors, green } \\
\text { areas separating traffic and pedestrians }\end{array}$ & $\begin{array}{l}\text { Building Standards / Limited-Income Housing } \\
21-05-1965 / \text { Technical Ordinances and } \\
\text { Building Standards / Limited-Income Housing }\end{array}$ \\
\hline \multirow{8}{*}{ 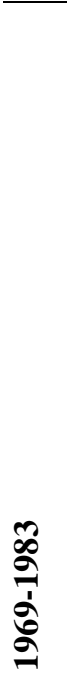 } & \multirow{8}{*}{1969} & $\begin{array}{l}\text { Adaptation to the Land Law. Globalising } \\
\text { character of the city. }\end{array}$ & $\begin{array}{l}20-05-1969 \text { / Technical Ordinances and } \\
\text { Building Standards / Limited-Income Housing }\end{array}$ \\
\hline & & & $\begin{array}{l}\text { 04-05-1970 / Modifications Technical } \\
\text { Ordinances and Constructive Standards / } \\
\text { Limited-Income Housing }\end{array}$ \\
\hline & & & $\begin{array}{l}\text { 20-06-1975 / Accessibility features for the } \\
\text { disabled / Limited-Income Housing. When } \\
>100 \text { dwellings, } 3 \text { adapted dwellings on } \\
\text { ground floor }\end{array}$ \\
\hline & & & \\
\hline & & & $\begin{array}{l}\text { 17-05-1977 / Standards of design and quality } \\
\text { of social housing / Social housing }\end{array}$ \\
\hline & & & 31-10-1978 / Guidelines to develop policies / \\
\hline & & & 25-01-1980 and 03-03-1980 / Access, lift and \\
\hline & & & $\begin{array}{l}\text { Interior Conditions for the disabled / Public } \\
\text { and private property buildings }\end{array}$ \\
\hline
\end{tabular}


9 zones: Z0 and Z1 Hc. Z2: Expansion of Hc. Z3 Grao area (sealine). Z4, Z5 and Z6 Peripheral groups. Z7-Z8 Low density / Hc:

1984 terraced single and multi-family houses. Z2Z3: high density blocks, up to 7 floors. Z4, Z5, Z6: miscellaneous

Z7, Z8: detached or terraced single-family houses.

Maintains the same zones of the previous planning with minor modifications / The same 2000 typologies as the previous planning

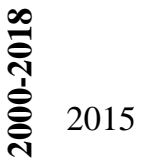

Subsidiary rules maintaining previous land planning / The same typologies as the previous planning

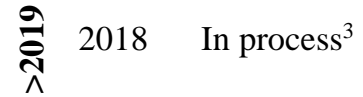

19-05-1989 / Minimum requirements on accessibility in buildings (lifts) / New buildings

22-04-1991 / Habitability and Design Standards in the Valencian Community / All housing, with some special measures for adapted housing for public or private use 01-01-1998 / Suppression of Architectural and Urban Barriers / Public buildings and urban environment.

05-03-2004 and 02-11-2009 / Accessibility Basic Requirements on Design and Quality in building / Public space and Residential buildings.

19-2-2010 / Specific Regulation on Accessibility ${ }^{4}$ All buildings

${ }^{1}$ Vivienda protegida: http://www.housingeurope.eu/resource-124/social-housing-in-europe); ${ }^{2}$ In Spanish: "Viviendas de renta mínima" (35-58 $\left.\mathrm{m}^{2}\right)$ and "Viviendas de renta reducida" (60-100 $\left.\mathrm{m}^{2}\right) .{ }^{3} \mathrm{New}$ Land-Use Plan information: http://www.plageneralcastello.es/ ${ }^{4}$ CTE-SUA. Technical Code for Building. Accessibility

\subsection{Public Social housing in Castellón}

We have selected public-owned social housing as representative of vulnerable buildings. Many authors highlight the relation of social housing with vulnerability parameters, and coincide in the convenience of intervening in this type of dwellings. Some highlight the social vulnerability of social housing neighbourhoods and analyse their obsolescence through their low energy efficiency (Santamouris et al., 2007; Della Valle et al., 2018; Sousa-Monteiro et al., 2017) or through their lack of accessibility (Apparicio and Seguin, 2006). Year of construction is another key point to assume greater vulnerability. An analysis of the evolution of building regulations in force during different temporal periods gives quite an accurate idea of the constructive features and general conclusions that can be inferred about the quality of buildings linked to their year of construction (Martín-Consuegra et al., 2018). Escandón et al., 2016, analysed social housing typologies, built between 1950 and 1980, in south Spain, and concluded that they presented a very low energy rating. Other aspects, such as greater deterioration and lack of accessibility of housing buildings from the late 1950 to the mid-1970s in Spain were pointed out by Ibarzola et al., 2018. Monzón and López Mesa, 2018, 
who developed a system of performance indicators to detect obsolete conditions of energy efficiency, airborne sound insulation and accessibility in multi-family housing blocks built during the 1939-1979 period in a case study of social housing in the city of Zaragoza. The authors highlight the special interest of local administrations in this housing type, which is considered one of the important building typologies for energy renovation in the buildings sector in the Spanish long-term strategy.

The social housing stock is formed by 223 dwellings in 41 blocks. The cadastral information, obtained from the Virtual Cadastral Office, provides year of construction, and buildings from 1957 to 1978 were found, 4 from the 50's, 28 from the 60's and 9 from the 70's. Multi-family buildings represented 37 of the 41 blocks as only four are single-family houses. Only two buildings, from the 50's, are completely public-owned.

\subsection{The neighbourhood scale: selection of the vulnerable area}

The selection of the neighbourhood is based on the ARRU report (García et al., 2017). It concluded by defining 17 areas of priority intervention in the city which permitted descending from the city to the neighbourhood scale. To do so, 29 ad hoc indicators were developed and grouped into four different categories: urban (6), building (6), socio-demographic (13) and socio-economic (4) by considering areas to be vulnerable when the four categories collided (multi-dimensional vulnerability). The indicators were selected by a panel of experts, assisted by participatory processes with citizens and also by focus groups techniques with vulnerable populations. This led to a comprehensive view of the areas in which the physico-social factors were considered. Table 2 summarises the indicators developed by Ruá et al, 2019. They were calculated at two levels: N1 indicators were calculated for the city scale by considering that most information was disaggregated at the census section level, which is an administrative border; N2, adapted to the vulnerable area scale, was linked with urban homogeneous borders. As further explained in the aforementioned reference, as regards the selection of indicators, it was based on available data and was performed by experts. They were 13 experts from the professional and academic worlds, s well as some technicians and advisors from local governments and organisms linked with social and urban fields. They all had seniority in their area of expertise and in-depth knowledge of the city. They considered the available objective data and the 
subjective information provided by the participatory processes with citizens. The former were taken basically from four main sources: National Statistics Office, Cadastral Office, Municipality, Police. The latter were acquired from holding 17 meetings in different neighbourhoods of the city. For scale N1, by implementing the focus groups technique; for scale $\mathrm{N} 2$, by including vulnerable population groups (women, the elderly, etc.). The developed model could be applied to different urban contexts, but each case would require the analysis of specific features to select ad hoc indicators.

Table 2. Indicators to evaluate vulnerable areas in Castellón (adapted from Ruá et al., 2019)

\begin{tabular}{|c|c|c|}
\hline Category & Indicator N1 & Indicator N2 \\
\hline \multirow{6}{*}{ 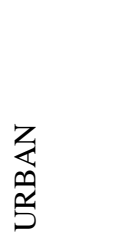 } & N1.U.01. Building density & N2.U.01. Building density \\
\hline & N1.U.02.Green areas & N2.U.02. Proximity to public transportation \\
\hline & N1.U.03. Proximity to public transportation & N2.U.03. Vacant lots \\
\hline & N1.U.04. Vacant lots & N2.U.04. Abandoned buildings \\
\hline & N1.U.05. Day sound level & N2.U.05. Accessibility in public space \\
\hline & N1.U.06. Night sound level & $\begin{array}{l}\text { N2.U.06. Residential - commercial activity } \\
\text { balance }\end{array}$ \\
\hline \multirow{6}{*}{ 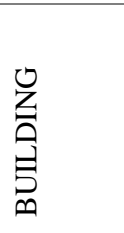 } & N1.B.01. Energy Efficiency & N2.B.01. Energy Efficiency \\
\hline & N1.B.02. Accessibility & N2.B.02. Accessibility \\
\hline & N1.B.03. Conservation & N2.B.03. Conservation \\
\hline & N1.B.04. Constructive quality & N2.B.04. Constructive quality \\
\hline & N1.B.05. Acoustic quality & N2.B.05. Acoustic quality \\
\hline & N1.B.06. Renewable energy & N2.B.06. Renewable energy \\
\hline \multirow{17}{*}{$\begin{array}{l}0 \\
0 \\
0 \\
0 \\
0 \\
0 \\
0 \\
0 \\
0 \\
0 \\
0 \\
0 \\
0\end{array}$} & N1.SD.01. Overcrowding & N2.SD.01. Overcrowding \\
\hline & N1.SD.02. Population $\geq 65$ years & N2.SD.02. Population $\geq 65$ years \\
\hline & N1.SD.03. Immigrants & N2.SD.03. Immigrants \\
\hline & N1.SD.04. Population $<15$ years & N2.SD.04. Population $<15$ years \\
\hline & N1.SD.05. Ageing 65/15 & N2.SD.05. Ageing 65/15 \\
\hline & N1.SD.06. Municipality's Social housing & N2.U.02. Proximity to public transportation \\
\hline & N1.SD.07. EIGE's Social housing (regional & N2.SD.06. Social housing Municipality \\
\hline & Administration) & N2.SD.07. Social housing EIGE \\
\hline & N1.SD.08. Children's vulnerability & N2.SD.08. Child vulnerability \\
\hline & N1.SD.09. Social services assistance & N2.SD.09. Social services assistance \\
\hline & N1.SD.10. Children's education & N2.SD.10. Children education \\
\hline & N1.SD.11. Noise complaints & N2.SD.11. Noise complaints \\
\hline & N1.SD.12. Social mediation services & N2.SD.12. Social mediation services \\
\hline & N1.SD.13. Housing & N2.SD.13. Housing \\
\hline & & N2.SD.14. Streets and weather problems \\
\hline & & N2.SD.15. Traffic \\
\hline & & N1.SD.16. Others \\
\hline \multirow{6}{*}{ 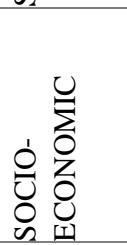 } & N1.SE.01. Social subsidies & N2.SE.01. Social subsidies \\
\hline & N1.SE.02. Dependence subsidies & N2.ES.02. Dependence subsidies \\
\hline & N1.SE.03. Level of education & N2.SE.03. Level of education \\
\hline & N1.SE.04. Absenteeism from school & N2.SE.04. Absenteeism from school \\
\hline & & N2.SE.05. Tax base \\
\hline & & N2.SE.06. Cadastral value \\
\hline
\end{tabular}

In this work, all the categories were considered to make up an overview. However, only the urban and building categories were analysed in depth to recommend some concrete Lines of Action linked to urban 
design by assuming that social policies should be undertaken concurrently to urban actions, and by considering that urban environment improvements would positively influence the social conditions.

The ARRU01, Castalia-La Guinea was selected. It is located to the NW of the city and is formed by part of the census sections $8001,8002,8003$ and 8005 . It comprises a total area of $208,793.40 \mathrm{~m}^{2}$ and the estimated population is 6,214 inhabitants. It contains 3,382 dwellings in 725 buildings, with a total built area of 336,864 $\mathrm{m}^{2}$, where the percentage of residential area over the total is $77.64 \%$.

In order to diagnose the vulnerable area scale in the selected ARRU the SWOT analysis is used. Different sources are employed. Nationally, the Spanish National Statistics Institute (INE) and the Atlas of Urban Vulnerability of the Spanish Ministry (http://atlasvulnerabilidadurbana.fomento.es/) are primary sources that provide useful macro-information on city and census section scales. More specific sources, such as the ENERFUND- Energy Retrofit Funding rating tool developed by the Valencian Building Institute (IVE), provides information about the energy performance of buildings (http://enerfund.eu/). On a regional scale, the tool Viewer of Sensitive Urban Spaces of the Valencian Government, VEUS for the Valencian Community. (https://visor.gva.es/visor/index.html?idioma=es\&capasids=VEUS;4,3,2,1,0). All these primary sources are useful for obtaining a general idea of the city that needs to be refined in a more accurate diagnosis. The ad hoc indicators developed for Castellón in the ARRU study were used.

All these data were analysed and summarised in SWOT and CAME matrices. Although the main conclusions of all the categories analysis were considered, the urban and building categories were further developed to implement urbanism actions, which will very likely have a positive influence on social dimensions, such as improved local economy and the amelioration of citizens' living conditions. Agost-Felip and Martínez (2018) published a report for the Municipality by enquiring about citizen's demands placed with Social Services for social aid in the different city districts (Centre, East, Grao, North, West, South). They recorded dependence benefits, minors' files, cases of absenteeism from school and social subsidies. The North District, where the ARRU studied in this work is located, presented more cases per inhabitant for the three first types of aid, and occupied second position, but not very far behind the first place (Centre District), for social aid. This indicates that this city district presents more social vulnerability. Regarding socio-demographic features, and according 
to García et al. (2017), the analysed area is characterised by a high percentage of elderly people and immigrants. This could lead to low social cohesion and social exclusion risk for vulnerable populations, and could be the cause of increased insecurity linked to marginality. As for the socio-economic features, the data showed some weaknesses, such as a high degree of subsidies dependence, high absenteeism rates from school and a lower level of education than other areas in the city. Besides, the data from the police revealed a considerable number of conflicts that have required police intervention. Moreover, a potential situation of energy poverty could be considered a threat in the area when taking into account the quality of buildings and the population's socio-economic status. However, potential urban regeneration can be seen as an opportunity linked to new jobs, increases in real-estate values and the activation of commercial premises. The SWOT and CAME matrices are presented in Figure 3. 


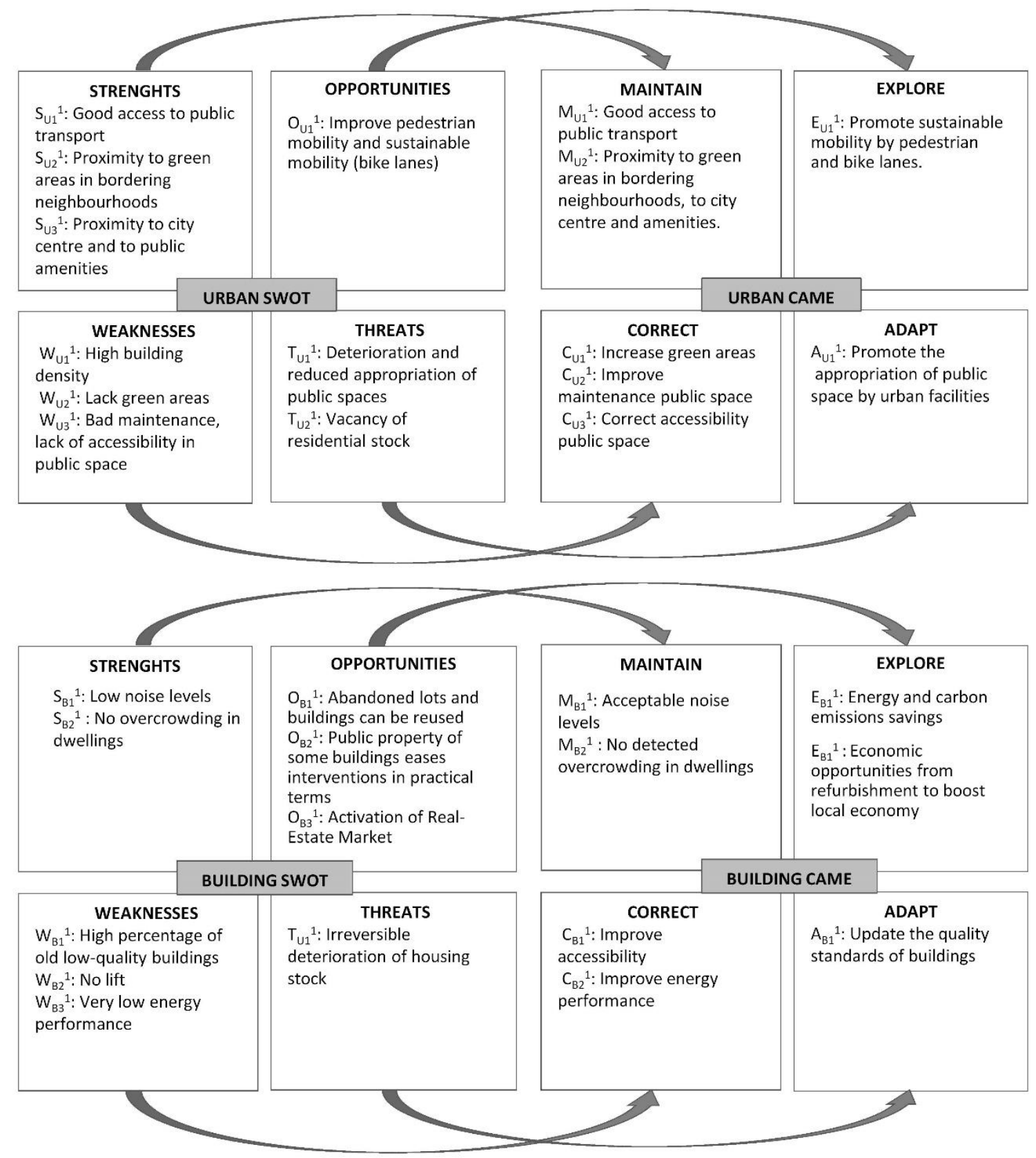

Figure3. SWOT and CAME matrix for Urban and Building category in ARRU01

From the CAME matrixes for the urban and building categories, Challenges $\mathrm{C}_{\mathrm{i}}^{\mathrm{n}}$ were inferred and the materialisation of each Challenge is achieved through the three Lines of Action for the urban category and one for building category. The ARRU01 location is shown in Figure 4 and the specific interventions suggested are presented in Figure 5 and Table 3. 


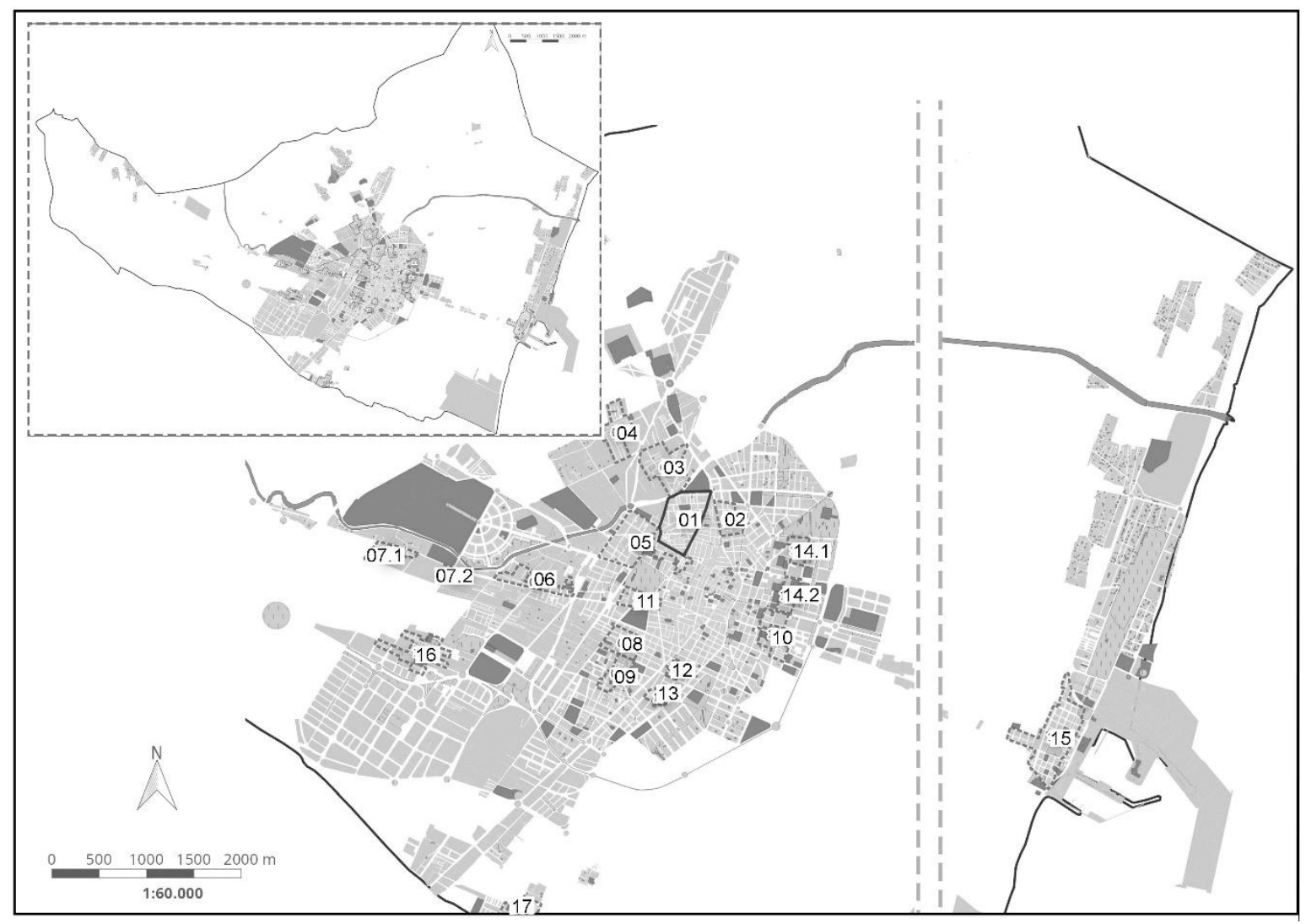

Figure 4. ARRU01 location 


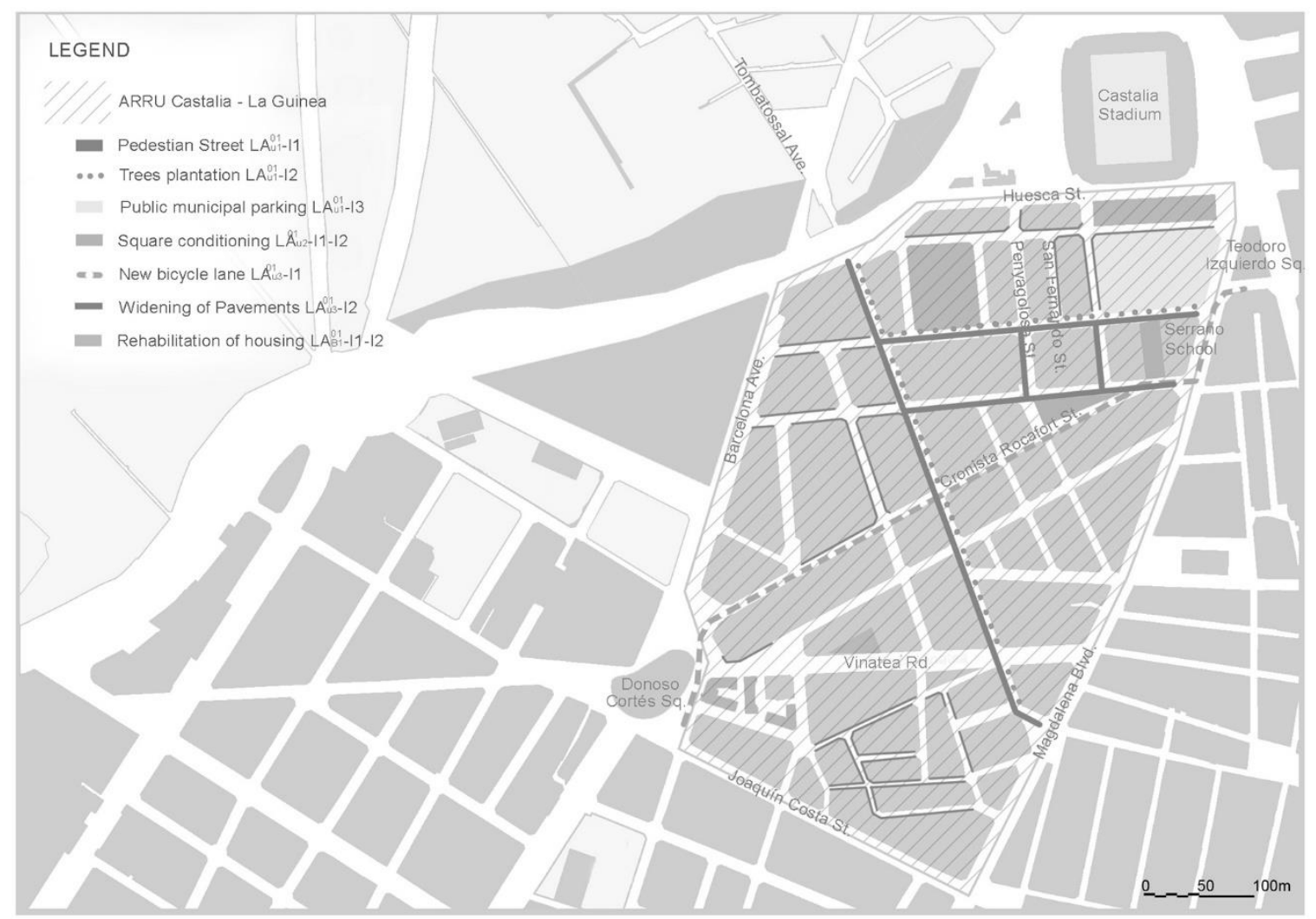

Figure 5. Lines of action

Table 3. Challenges and Lines of Action suggested at urban scale

$\mathrm{C}_{\mathrm{U}}{ }^{01}$. Reverse the urban deterioration process, improve the environment by conditioning green spaces, and propose spaces for leisure activities for children, young people and the elderly

$\mathrm{LAu}^{01}$ Promote the recovery of the urban fabric and improve the connectivity of public spaces.

Interventions

- I1. Pedestrian streets: Pedestrianalization of Segorbe Street to connect the Castalia Stadium to the ARRU03, through Tombatossal Avenue, and to the ARRU04, through Diputación Avenue Ii improves student's autonomy to access the School.

- I2. Trees Plantation: Deciduous trees allow sunlight to pass in winter and provide shade in summer to thermally regulate the urban space. They also improve the quality of the air.

- I3. Public municipal parking: Cars are moved for pedestrian space and vacant lots are used.

Budget*: 1,361,565.90€

Monitoring Indicators**: N1.U.02. Green áreas. N2.U.04. Vacant lots

$\mathrm{LA}_{\mathrm{U} 2}{ }^{01}$ Reorder, recover and condition public spaces and existing green areas. Encourage urban appropriation. Provide favourable conditions for the use of public spaces. Intervention

- I1. San Fernando-Penyagolosa Square improvement: Introduce urban furniture such as benches, sport urban facilities appropriate specially for the elderly and the children. This is aimed to improve the physical and psychic well-being of citizens, specially the most vulnerable, and to promote social 
relations.

- I2. New Square: Create a New Plaza LAU201-I2 for children and elderly, connecting the green area that exists behind the nursery and the ground occupied by the unused industrial units shown in the image. It is proposed naming the square considering gender mainstreaming, using the name of a relevant woman.

Budget*: 256,993.00€/

Monitoring Indicators**: N1.U.02. Green areas. N2.U.04.Abandoned buildings

$\mathrm{LA}_{\mathrm{U} 3}{ }^{01}$ Sustainable mobility: improve the cyclist network and pedestrian accessibility Budget*: 106,524.00€/

Monitoring Indicators**: N2.U.03. Proximity to public transportation. N2.U.05. Accessibility in public space

Intervention

- I1. New bicycle lanes: New bicycle lane, $2 \mathrm{~m}$ width and independent from sidewalk. It will go from Donoso Cortés Square to Teodoro Izquierdo Square, where currently public bicycle sharing system is available. It will cross the ARRU diagonally, along Cronista Rocafort ad Teniente Monzonís Streets. It reduces car traffic, improves the quality of the air and the health of the users.

- I2. Widening of sidewalks: Remodeling of pavements in bad maintenance state (see plans). Widening of sidewalks under $1.80 \mathrm{~m}$. It fulfils the accessibility requirements, according to updated regulations (access ramps, appropriate pavements adapted to disabled such as podotactile pavement...). This solution improves pedestrians mobility and guarantees universal accessibility.

Budget*: 106,524.00€

Monitoring Indicators**: N2.U.03. Proximity to public transportation. N2.U.05. Accessibility in public space.

\section{CB01. Energy performance and accessibility improvement in buildings.}

\section{$\mathrm{LA}_{\mathrm{B} 1}{ }^{01}$ Promote rehabilitation, renovation and access of obsolete housing}

\section{Intervention}

- I1. Energy performance improvement: It is aimed to reduce energy demand and carbon emissions and to improve the thermal comfort and acoustic properties and general state of the building. To do so, it is suggested to add insulation in thermal envelope and double glazing and higher tightness level in carpentries. Also more efficient facilities for heating, cooling and domestic hot water needs are suggested. Constructive solutions should be adapted to the specific features of the building.

- I2. Accessibility improvement: It should consider especially for the elderly, or disabled people. It consists in the installation of an elevator and the removal of steps, when needed. Constructive solutions should be adapted to the specific features of the building regarding to accessibility.

Budget*: it depends on the specificities of the refurbishment (see suggestions in Table 3)

Monitoring Indicators**: N2.B.01. Energy Efficiency. N2.B.02. Accessibility. N2.B.03. Conservation. N2.B.04. Constructive quality.

*Detail of budget in García et al, 2017 (Chapter IV). Prices obtained from prices database of the Building Valencian Institute (IVE, 2016. Available at https://www.five.es/productos/herramientas-on-line/visualizador2016/, last accessed 2019 December, 26th); **Detail Indicators in Ruá et al, 2019.

\subsection{The Building scale}

A relevant conclusion of the ARRU study was that, although not all the indicators were vulnerable, practically all of them were when considering the building category as a direct relation was found between multidimensional vulnerability and building vulnerability. Accordingly, this work focuses on social housing and 
descends to the building scale. According to the ARRU report, the ARRU01 presents the highest value for the indicator "Social Housing of Municipality".

Considering the scope of this case study, the neighbourhood scale is represented by an ARRU and the building diagnosis is made by using the IEE. The report considers that three variables are to be analysed: conservation state, energy performance and accessibility, respectively represented by $\mathrm{Q}_{1}, \mathrm{Q}_{2}$ and $\mathrm{Q}_{3}$.

In general terms, the conservation and energy performance of some buildings in the study area need to improve and basic accessibility facilities have to be implemented, as reflected in the SWOT-CAME analysis on the building scale (see Fig. 3). Most of buildings in the area are more than 50 years old. However, there are many differences in the extent of the intervention depending on the specific features of the building, such as construction systems, state of conservation, exact location, etc. The analysis of their specificities offers an accurate diagnosis to propose ad hoc interventions.

In this work, a public-owned social housing building was selected to suggest adequate refurbishment solutions and to estimate an accurate budget. It is a large block built in the late 1950s that is located in the selected urban area.

Appropriate refurbishment measures for this block, named $\mathrm{B} 1$, were proposed for variables $\mathrm{Q}_{1}, \mathrm{Q}_{2}$ and $\mathrm{Q}_{3}$ according to the IEE. The available project documentation was examined. Data collection took place after making some visits to the block and some dwellings.

The block was built in 1959 by a Ministry of Housing subsidy. It is formed by six buildings facing north and six buildings facing south, and it lies around an internal courtyard. Each building is formed by 10 dwellings: two on the ground floor and two on all four upper floors. All together, they sum 2,339 $\mathrm{m}^{2}$ and 120 dwellings, which represents about $54 \%$ of the total municipal housing stock.

In order to justify the universality of the SWOT CAME method, we followed an analogical methodological procedure by presenting an example of another social housing block in the city, and we found some differences in the refurbishment proposal due to each building's specific features. The second building is located in another defined vulnerable area, ARRU10, named 14 de Junio-Grapa, in the East city district. This area, which covers $82,188.04 \mathrm{~m}^{2}$, and has 97 buildings and 1,865 dwellings in all, presents an old urban fabric 
and obsolete buildings, such as ARRU01. With 3,495 inhabitants, it is characterised by a high ageing index and a large immigrant population. The selected block of buildings, named B2, was built in 1959 and was also of municipal property, with 50 dwellings in all. Together with the previous building, they accounted for around $76 \%$ of the municipal owned social housing in the city. In fact both ARRU present the first and second higher indicators for municipal social housing. In this second case, the block is formed by five semi-detached buildings, with 10 dwellings each, on the ground level, as well as four floors, which accounted for a total of 50 dwellings.

Table 4 presents the main features, conservation state, energy performance and accessibility diagnosis for both buildings. Further information is presented in Appendix B.

\subsubsection{Variable $Q_{1}$ : Energy Performance}

The detailed analysis of the thermal envelope and the facilities used for domestic hot water, heating and cooling was performed to analyse the building's energy performance using an official energy certification tool (CE3x) that permits a building's energy performance to be estimated through simulation. The measures proposed to improve energy performance were selected by a multi-criteria evaluation of different measures and by considering technical, environmental, economic and aesthetic criteria (Ruá et. al, 2018).

The block structure is made by bearing walls formed by double leaf brick. The street- facing walls are formed by an exterior masonry wall of solid ceramic brick (1 foot-thick) and an inner skin of hollow ceramic $4 \mathrm{~cm}-$ thick brick, finished with plastering. Single-glazed windows are made of wood, have poor air-tight quality and are usually badly maintained. Two roof types can be found, flat roof ventilated, trafficable; gable-sloping roofing, ventilated $16^{\circ}$. No insulation at all can be seen in any constructive sections, which implies very poor heat performance. Most dwellings lack a climate-control system, although some may have individual heaters or coolers. Individual electrical heaters are used for domestic hot water. All together, they result in the building's low energy performance, and an E-letter energy label ${ }^{1}$ that can be improved to ensure thermal comfort, ameliorate possible energy poverty situations and reduce both energy bills and carbon emissions. Similar constructive solutions are found in block B2.

1 Energy labels in Spain by evaluating buildings in Spain, and represented on a scale from A to G by depicting the best to the worst energy performance. 
In both cases (B1 and B2), the proposal is to improve thermal envelope performance, basically by adding insulation: façades with an external thermal insulation composite system (ETICS), change the carpentries of windows and use double glazing, and a layer of inner mineral wool and plaster board in roofs. Regarding facilities, natural gas high-efficiency heaters are installed for domestic hot water and heating with individual heaters. Thermal simulation shows an improved energy label from $\mathrm{E}$ to $\mathrm{C}$, which means savings in energy use and carbon emissions.

The cost estimation of the proposed investment is $€ 10,519.56 /$ dwelling in B1 and $€ 13,329.38 /$ dwelling in B2, ( $€$ in 2017). The economic analysis was conducted by the cost-optimal method, according to the Commission Delegated Regulation (EU) 244/2012, of 16 January 2012, which supplements Directive 2010/31/EU of the European Parliament and the Council on the energy performance of buildings by establishing a comparative methodology framework to calculate cost-optimal levels of minimum energy performance requirements for buildings and building elements. It gave a Net Present Value over zero after 20 years. This term would be shorter if subsidies could address buildings. Location in an ARRU means that it is an area that should be

prioritised to address potential subsidies. Refurbishment would also benefit users' thermal comfort by reducing potential energy poverty situations. The market price of dwellings would increase, as would the potential positive effect on local economy, which were not considered in that the cost-optimal method.

\subsubsection{Variable $Q_{2}$ : Conservation}

The structure of both blocks reveals no cracks or bending in structural elements. However, the envelope and flat roofs of both blocks are not generally maintained. The aesthetics of the entire façade is expected to be updated with the energy performance solution for façades and windows. B1 does not need any further intervention, although B2 present some rising dump problems on façades.

\section{Variable $Q_{3}$ : Accessibility}

For the accessibility study, reference was made to the regulations in force in the Valencian Community, DC09 on the Conditions of Design and Quality in Housing and Accommodation Buildings, together with the Basic Document on Safety in the Use and Accessibility of the Technical Code in Building. 
At the time the building was built, accessibility regulations were practically non-existent. In practical terms, they were limited to the use of staircases to allow access to the different levels. Thus the five levels of the 12 buildings into which the block B1 is divided are vertically communicated by stairs with a $75 \mathrm{~cm}$ width. To climb the $3.15 \mathrm{~m}$ that separate each level, 18 steps are used, which are distributed into two parallel flights, each with eight steps, plus two on the staircase landing.

In front of these staircases, entrance halls contain other steps because the street slopes. This slope follows the block's west-east direction, thus the number of steps differs in each entrance hall, and vary from the eight in the east end entrance hall to just one in the west end.

The proposed intervention is divided into two different works. On the one hand, we need to overcome the deficiencies observed in accessing the building's different floors; on the other hand, it is necessary to remove the different steps on the ground floors due to the sloping street.

To solve the first part, and given the dimensional deficiencies of the present stairs, building six new vertical communication cores located in the inner courtyard is proposed. Each one consists in a new staircase and a lift. Each would serve two of the buildings, and would allow the present staircases to be removed.

The second action is overcome in a unitary manner for the whole block. To this end, access to each entrance hall can be achieved from the inner courtyard by removing the present stairs, and also due to the level of the inner courtyard rising to gain access to the ground floor dwellings. From the outside, the inner courtyard would be accessed from each entrance hall. However, those dwellers who need to avoid steps can use the two entrance halls located in the west end, where the little slope can be overcome with a $10 \%$ sloping ramp (Figure 6).

The cost estimation for this intervention in ARRU01 is $€ 9,724.12 /$ dwelling (€, 2017). This cost could be lower thanks to State subsidies for the conservation, improved use and accessibility of dwellings in this building type, which was built before 1996. This reduction could be as much as $40 \%$ of the overall budget, and even $75 \%$ for those owners aged over 65 years. 

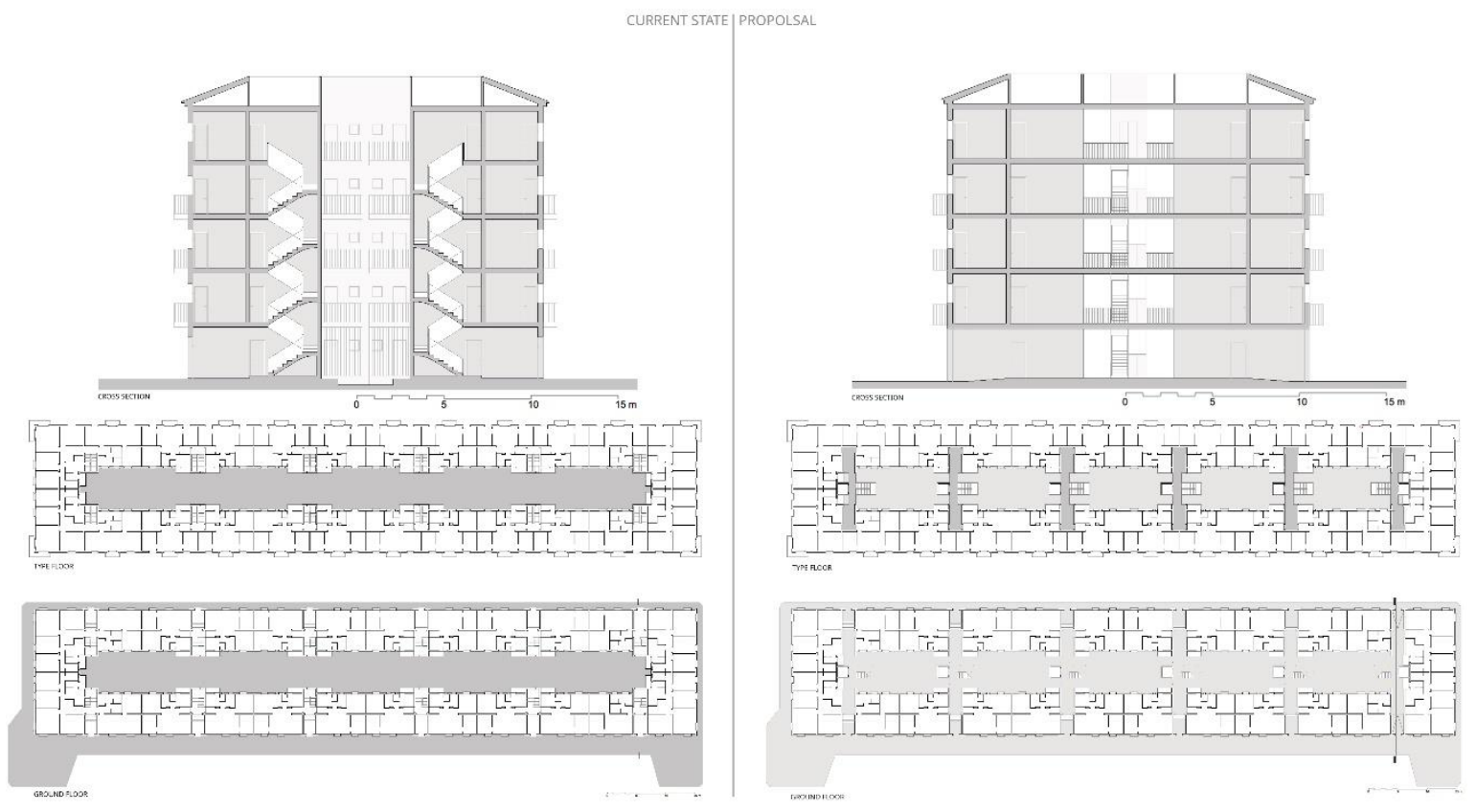

Figure 6. Accessibility. Current state and proposal

The solution differs in block B2. Construction features are similar to the ARRU01 buildings but, in this case, there is no inner courtyard. Therefore, refurbishment solutions could be similar for efficiency improvements. The conservation state of this particular building shows some dump problems on the north façade. Thus intervention is required to achieve an appropriate conservation state, and a solution based on passive electroosmosis is suggested (690.20 €/dwelling). The only solution for accessibility improvement in this particular case would be to build a centre of vertical communication, attached to the façade install lifts to access upper floors. This solution is technically similar to the other one, but implies occupying public space, which would entail obtaining permission for this intervention. Besides, there are stairs that access the building from the street, and other stairs that access the ground floor dwellings, which could be solved by ramps and stair lifts, respectively. The estimated cost of this intervention in ARRU10 is $€ 10,517.21 / \mathrm{dwelling}$ ( $€$ in 2017). 
Table 4. Specific solutions suggested at building scale

\section{Q1. Conservation improvement}

Current State

- General lack of maintenance in façades and roofs.

- Rising dump in comparative building B2.

Intervention

- Façades: External Thermal Insulation System and new windows will improve the aesthetics.

- Roofs: cleaning and maintenance tasks $(2,622.00 €$ in B1 and 1,966.50€ in B2).

- Rising dump: only in B2. Passive electro-osmosis system is suggested before ETICS is installed $(28,509.80 €)$.

\section{Q2. Energy performance improvement}

Current State

- No insulation in façades and roof

- Wood carpentry with single glazing

- No heating and cooling

- Electrical boilers for domestic hot water (DHW)

Intervention

- Façades: External Insulation System.

- Windows: Double glazing windows.

- Roofs: inner solution involving mineral wool and finishing plaster board.

- Facilities: install condensed heater with natural gas for heating and DHW.

\begin{tabular}{l|ccc|ccc}
\hline & ARRU01-B1 & & \multicolumn{3}{l}{ ARRU10-B2 } & \\
\hline Results & Current & Refurbished & Saving \% & Current & Refurbished & Saving \% \\
\hline $\begin{array}{l}\text { Heating demand } \\
\mathrm{kWh} / \mathrm{m}^{2}\end{array}$ & $64.5 \mathrm{~F}$ & $17.5 \mathrm{C}$ & 72.8 & $79.7 \mathrm{G}$ & $27.2 \mathrm{D}$ & 65.8 \\
\hline $\begin{array}{l}\text { Cooling demand } \\
\mathrm{kWh} / \mathrm{m}^{2}\end{array}$ & $17.8 \mathrm{D}$ & $14.7 \mathrm{D}$ & 17.3 & $22.1 \mathrm{E}$ & $13.3 \mathrm{C}$ & 39.6 \\
\hline Heating emissions & $16.0 \mathrm{E}$ & $4.3 \mathrm{C}$ & 72.8 & $21.8 \mathrm{E}$ & $7.5 \mathrm{D}$ & 65.8 \\
\hline Cooling emissions & $5.1 \mathrm{D}$ & $4.2 \mathrm{D}$ & 17.3 & $3.7 \mathrm{D}$ & $2.2 \mathrm{C}$ & 39.6 \\
\hline DHW emissions & $8.4 \mathrm{G}$ & $6.7 \mathrm{G}$ & 19.9 & $10.7 \mathrm{G}$ & $6.6 \mathrm{G}$ & 38.4 \\
\hline $\begin{array}{l}\text { Global emissions } \\
\text { Kg CO } / \mathrm{m}^{2}\end{array}$ & $29.5 \mathrm{E}$ & $15.3 \mathrm{D}$ & 48.1 & $36.2 \mathrm{E}$ & $16.3 \mathrm{D}$ & 55.1 \\
\hline $\begin{array}{l}\text { Budget*: } € 10,519.56 / \text { dwelling; Total } \\
\text { Total B1: } € 666,469.38\end{array}$ & & & & & \\
\hline
\end{tabular}

Current state

- Only staircases.

- Step width 0.75 meters ( 0.82 meters in comparative building)

- Height difference between ground level and entrance halls levels is solved with steps.

Intervention

- Staircases + lifts (lift in internal courtyard in building B1 and attached to the north façade in comparative building B2)

- Step width > 1.00 meter.

- Height difference between ground level and the entrance halls levels is solved with a slope ramp $<10 \%$.

Budget*: Total B1: $€ 1,166,894.40 ; € 9,724.12 / d w e l l i n g . \quad$ Total $\mathrm{B} 2: \quad € 525,860.76$;

$€ 10,517.21 /$ dwelling;

* Prices obtained from prices database of the Building Valencian Institute (IVE, 2017. Available at https://www.five.es/productos/herramientas-on-line/visualizador-2017/, last accessed 2020 July, 22nd). 


\section{Discussion and conclusions}

The built environment constitutes the physical context in which human activities and relationships occur. So intervening on urban and building scales profoundly influences the social perspective. The urban regeneration of vulnerable areas should be prioritised to reduce their citizens and users' vulnerability, and to improve their well-being by achieving social benefits and overcoming vulnerability.

This work proposes a model for decision-making support to help Administrations to undertake urban regeneration. It is formed by a three-scale model: city, neighbourhood and building.

The city scale was founded on the analysis of urbanism and buildings regulations, together with the urban development study of this city. They provide a view of its urban features.

The identification of vulnerable areas permits descent to the neighbourhood scale where the use of a SWOT analysis is proposed. This methodology, used more in business contexts, has not often been used for urban regeneration. However, due to the variety of factors forming urban environments, it is considered a useful and practical tool to arrange and structure information. Nevertheless, it needs to be grounded in well-founded information to achieve an accurate diagnosis. The complementary CAME methodology can be easily inferred from the SWOT matrix to suggest general urban regeneration guidelines. We found no reference about using this complementary methodology in urban regeneration. The combination of both methodologies proved useful for identifying the determining factors of vulnerability to prioritise the areas to regenerate. From this point, specific Challenges can be set out and can later materialise through specific the Lines of Action, adapted to the specific needs in the studied area. Finally, they can be presented and summarised on useful and practical datasheets.

Finally, the building scale aims to prioritise interventions on this scale. Interventions in public space, such as pavements, parks, etc., are easy to standardise and it is simple to estimate the economic cost of interventions. However, the buildings included in an area are distinct in terms of their age, typology, structural and constructive features. Therefore, a building's vulnerability varies and refurbishment solutions cannot be standardised. The proposal herein presented is to intervene in social housing of municipal property as being 
representative of vulnerable buildings. The selection of one or some specific buildings allows an optimum refurbishment proposal to be made.

The general proposed methodology can be replicated in different contexts, although urban contexts vary and building features differ. To do so, a well-founded analysis must be carried out on all the proposed scales in order to obtain results that can help decision making in practical terms.

The city of Castellón was selected as an empirical case to validate the proposed model. A vulnerable neighbourhood was selected and analysed to suggest urban regeneration measures that adapt to its specificities, and two social housing blocks were examined in-depth to propose ad hoc refurbishment measures, which was necessary to propose tailored measures and to estimate an economic cost of interventions. This will permit Administrations to allocate funds for urban regeneration as an improvement opportunity for these distressed areas.

\section{References}

Agost-Felip, M.R. and Martínez Martínez, L. (coord.) (2018). Atención a la ciudadanía realizada desde los servicios sociales para orientar las políticas y programas de prevención y protección social en el área de servicios sociales del Ayuntamiento de Castelló: estudio territorial y sectorial. Research Report.

Álvarez A.; Roch F. (Directors), University of Valladolid, 2010, Integrated Urban Regeneration in Europe, Summary Document, retrieved from https://www.fomento.es/NR/rdonlyres/F3B6A30E-5554-40EDA804-27FBD3E4B275/95965/URBAN_REGENE_ENGLISH.pdf, last accessed 24 July 2020.

Apparicio, P. and Seguin A.M. Measuring the Accessibility of Services and Facilities for Residents of Public Housing in Montreal (2006). Urban Studies, 43 (1), 187-211. https://doi.org/10.1080/00420980500409334

Arriba, A. and Rodríguez, G., Housing Plan in Spain for 2018-2021 . European Social Policy Network. ESPN Flash Report 2018/58, 18 July. 
Balaras, C.A., Droutsa, K., Dascalaki, E.G and Kotoyiannidis, S. (2018, December). Holistic Sustainability Assessment Systems for Buildings and Neighborhoods, 49th International HVAC\&R Congress and Exhibition, Belgrade, Serbia. http://doi.org/10.24094/kghk.018.49.1.239

Barosio, M.; Eynard, E.; Marietta, C.; Marra, G.; Melis, G.; Tabasso, M (2016). From urban renewal to urban regeneration: Classification criteria for urban interventions. Turin 1995-2015: Evolution of planning tools and approaches. Journal of Urban Regeneration and Renewal, Vol. 9, 4, 367-380

Casanova, H. and Hernández, J. (2014). Public Space Acupucture. Actar Publishers, New York, United States.

Cohen, M. (2017). A Systematic Review of Urban Sustainability Assessment Literature. Sustainability, 9(11), 2048; https://doi.org/10.3390/su9112048

Couch, C.; Sykes, O.; Börstinghaus, W. (2011). Thirty years of urban regeneration in Britain, Germany and France: The importance of context and path dependency. Progress in Planning 75, 1-52.

Conway, M. and Konvitz, J. (2000). Meeting the challenge of distressed urban areas. Urban Studies, 37(4), 749-774.

Crescenzo, M., De Matteis, S., Bottero, M., Berta, M. and Ferretti, V. (2018). An embedded Mixed-Methods Approach to evaluating Regeneration Strategies for the Historic Center of Trieste. In integrated evaluation for the management of contemporary cities. Book series Green Energy and Technology, pp. 133-147. https://doi.org/10.1007/978-3-319-78271-3_11.

Della Valle N., Bisello A. and Balest J. (2018). In search of behavioural and social levers for effective social housing retrofit programs. Energy and Buildings, 172, 517-524. https://doi.org/10.1016/j.enbuild.2018.05.002 
De Magalhães, C. (2015). International Encyclopedia of Social \& Behavioral Science 2nd Edition. Pages 919-925. Elsevier. London, UK.

De Sola Morales, M. (2008). A Matter of Things, Rotterdam, NAi Publishers.

Doo-Hwan, K. and Byung-Ju A. (2009). The Strategic Approach Using SWOT Analysis to Develop an Intelligent Program Management Information System (iPMIS) for Urban Renewal. 2009 Fourth International Conference on Computer Sciences and Convergence Information Technology Projects. DOI: 10.1109/ICCIT.2009.133

Doretli, N., Hoskara, S.O. and Fasli, M. (2004). An analytical methodology for revitalization strategies in historic urban quarters: a case study of the Walled City of Nicosia, North Cyprus. Cities, 21, 329-348. https://doi.org/10.1016/j.cities.2004.04.009

Enia, M. and Martella, F. (2019). Reducing architecture: Doing almost nothing as a city-making strategy in 21st century architecture. Frontiers of Architectural Research 8, 154-163.

Esteve-Comes, A. (2012). Paseando por las calles de Castellón. Ed. Creamos Talentos literarios, Castellón.

Ferreti, V. and Gandino, E. (2018). Co-designing the solution space for rural regeneration in a new World Heritage site: A choice Experimental approach. European Journal of Environmental Research, Vol. 268 (3), pp.1077-1091. https://doi.org/10.1016/j.ejor.2017.10.003

García-Bernal, D., Huedo, P., Babiloni, S., Braulio, M., Carrascosa, C. and Civera, V. (2017). Estudio y propuesta de áreas de rehabilitación, regeneración y renovación urbana, con motivo de la tramitación del Plan General Estructural de Castellón de la Plana. On line, https://s3-eu-west1.amazonaws.com/urbanismo/TOMO_I.pdf; https://s3-eu-west-1.amazonaws.com/urbanismo/TOMO_II.pdf; https://s3-eu-west-1.amazonaws.com/urbanismo/TOMO_III.pdf; ～https://s3-eu-west1.amazonaws.com/urbanismo/TOMO_IV.pdf. Accessed on: 18 May 2018. 
Generalitat Valenciana, Conselleria d'Habitatge, Obre Públiques i Vertebració del Territori and Institut Valencià de l'E dificació (2018). Directrices para el desarrollo de Estrategias de Regeneración Urbana para municipios de la Comunitat Valenciana (Guidelines to Develop Urban Regeneration Strategies in the Valencian Region, ERU), Versión V.2, julio 2018. On line, http://www.habitatge.gva.es/documents/20558636/166160274/DIRECTRICES_ERU_V2_Julio_2018.pdf/72e f21b7-702e-4151-99a8-f6e3c0b182a8. Accessed on 29 Apr. 2019.

Gürel, E., Tat, M. (2017). SWOT analysis: a theoretical review. The Journal of International Social Research, 10 (51). http://dx.doi.org/10.17719/jisr.2017.1832

Lee, S. and Sai On Ko, A. (2000). Building balanced scorecard with SWOT analysis and implementing "Sun Tzu's The Art of Business Management Strategies” on QFD methodology, Managerial Auditing Journal, Vol. 15 (1/2), pp. 68-76. https://doi.org/10.1108/02686900010304669

Hernández Aja, A., Matesanz Parellada, Á., Rodríguez-Suarez, I., García Madruga, C. (2015). Evolución de las políticas de rehabilitación en Áreas de Rehabilitación Integrada en España (1978-2012). Informes de la Construcción, 67(EXTRA-1): m024, doi: http://dx.doi.org/10.3989/ic.14.057.

Lee, Y.J. (2014). Social vulnerability indicators as a sustainable planning tool. Environmental Impact Assessment Review, 44, 31-42. https://doi.org/10.1016/j.eiar.2013.08.002

Lerner, J, (March 2007), Jaime Lerner sings of the city, Montery, California, retrieved 23rd July 2020 from http://www.ted.com/talks/lang/eng/jaime_lerner_sings_of_the_city.html

Martín-Consuegra, F., de Frutos, F., Oteiza, I. and Hernandez-Aja, A. (2018). Use of cadastral data to assess urban scale building energy loss. Application to a deprived quarter in Madrid. Energy and Buildings, 171, 5063. http://dx.doi.org/10.1016/j.enbuild.2018.04.007 
Mehmet, M.C. and Yakup, E. (2016). A sustainable Approach to Urban Regeneration Process by SWOT analysis. International Journal of Environmental Science, Vol.1, pp. 34-40.

Monzón, M., López-Mesa B. (2018). Buildings performance indicators to prioritise multi-family housing renovations. Sustainable Cities and Society, 38, 109-122. https://doi.org/10.1016/j.scs.2017.12.024

Mosannenzadeha, F., Di Nuccic, M.R. and Vettorato, D. (2017a). Identifying and prioritizing barriers to implementation of smart energy city projects in Europe: An empirical approach. Energy Policy, 105, 191201. http://dx.doi.org/10.1016/j.enpol.2017.02.007

Mosannenzadeh F., Bisello A., Vaccaro R., D'Alonzo V., Hunte, G.W. and Vettorato D. (2017b). Smart energy city development: A story told by urban planners. Cities, 64, 54-65. http://dx.doi.org/10.1016/j.cities.2017.02.001

Naterer, A., Žižek, A. and Lavrič, M. (2018). The quality of integrated urban strategies in light of the Europe 2020 strategy: The case of Slovenia. Cities 72, 369-378. https://doi.org/10.1016/j.cities.2017.09.016

Natividade-Jesus E.; Almeida, A.; Sousa, N. and Coutinho-Rodrigues, J. (2019). A Case Study Driven Integrated Methodology to Support Sustainable Urban Regeneration Planning and Management. Sustainability, 11(15), 4129; https://doi.org/10.3390/su11154129

Pickton, D.W. and Wright, S. (1998). What's swot in strategic analysis? Strategic Change, 7, pp.101-109. https://doi.org/10.1002/(SICI)1099-1697(199803/04)7:2<101::AID-JSC332>3.0.CO;2-6

Ruá M.J., Huedo, P., Cabeza M., Saez B. and Civera, V. (2018).Energy rehabilitation of social housing in vulnerable areas. Case study: a 1950s building in a medium-sized Mediterranean city. Environmental Science and Sustainable Development, March, p. 44-59. https://doi.org/10.21625/essd.v4i1.490 
Ruá, M.J., Huedo, P., Civera, V. and Raquel Agost-Felip. (2019). A simplified model to assess vulnerable areas for urban regeneration. Sustainable Cities and Society, 46, 101440. https://doi.org/10.1016/j.scs.2019.101440.

Ryan, C. (2013). Eco-Acupuncture: designing and facilitating pathways for urban transformation, for a resilient low-carbon future. Journal of Cleaner Production 50, 189-199

Salar, M. and Salar, O. (2014). Determining Pros and Cons of Franchising by Using Swot Analysis. Procedia - Social and Behavioral Sciences, 122, pp. 515-519. https://doi.org/10.1016/j.sbspro.2014.01.1385

Sánchez-Cantalejo, C., Ocana-Riola, R. and Fernández-Ajuria, A. (2008). Deprivation index for small areas in Spain. Social Indicators Research, 89, 259-273. https://doi.org/10.1007/s11205-007-9114-6.

Santamouris M., Kapsis K., Korres D., Livada I., Pavlou C. and Assimakopoulos M.N., (2007). On the relation between the energy and social characteristics of the residential sector. Energy and Buildings, 39 (8), 893-905. https://doi.org/10.1016/j.enbuild.2006.11.001

Soliman, A. (2012). Building bridges with the grassroots: housing formalization process in Egyptian cities. Journal of Housing and Built Environment, 27, 241-260. https://doi.org/10.1007/s10901-011-9251-8.

Sousa Monteriro, C., Causone, F., Cunha, S., Pinha, A. and Erba, S. (2017). Adressing the challenges of public housing retrofits. Energy procedia, 134, 442-451. https://doi.org/10.1016/j.egypro.2017.09.600

Unt, A.L. and Bell, S. (2014). The impact of small-scale design interventions on the behaviour patterns of the users of an urban wasteland. Urban Forestry \& Urban Greening, 13, 121-135 
Warren, J., Morri, E., Enoch, M., Padilla-Magdaleno, I., Parra-Arias, Z. and Guanche, J. (2015). Developing an equitable and sustainable mobility strategy for Havana. Cities 45, 133-141. https://doi.org/10.1016/j.cities.2015.02.007

Wei Zheng, H.W., Qiping Shen, G.Q and Wang, H. (2014). A review of recent studies on sustainable urban renewal. Habitat International, 41, 272-279. http://doi.org/10.1016/j.habitatint.2013.08.006. 


\section{Acknowledgments}

We thank the INPRU-CS company and the Municipality of Castellón de la Plana for providing the data for research purposes.

The Municipality of Castellón obtained public funds for urban regeneration for the neighbourhood that was considered in this work. These funds were published in the Provision of the General Directorate of Housing and Bioclimatic Architecture of the Valencian Government in the Regional Official Gazette number 8666 dated $17^{\text {th }}$ Oct 2019 (available at http://www.dogv.gva.es/va/disposicio?sig=009292/2019\&url lista=, last accessed $27^{\text {th }}$ Dec 2019 ). The proposal presented by the Municipality to the Valencian government was based on the suggestions presented in this study.

\section{Funding}

The authors disclosed receipt of the following financial support for the research, authorship and publication of this article: this work was supported by the Valencian Regional Government (Conselleria d'Educació, Investigació, Cultura i Esport de la Generalitat Valenciana) through Project [GV/2017/110]. 


\section{$\mathrm{LA}_{\mathrm{U} 1}{ }^{01}$ Promote the recovery of the urban fabric and improve the connectivity of public spaces}

\section{OBJECTIVES}

Improve the connectivity of urban fabric promoting the appropriation of public space, through the increase of walkable lanes and green areas.

\section{INTERVENTIONS}

11. Pedestrian streets

12. Trees Plantation

13. Public municipal parking

\section{BUDGET*}

$1,361,565.90 €$

\section{MONITORING INDICATORS**}

N1.U.02. Green areas

N2.U.04. Vacant lots

\section{I1. PEDESTRIAN STREETS}

Perimeter streets to the Castalia public School:

Segorbe, Maestro

Caballero, Hermanos

Vilafaña and Penyagolosa

Streets.

12. TREES PLANTATION

Trees plantation

Deciduous trees that allow sunlight to pass in winter and provide shade in summer to thermally regulate the urban space. They also will improve the quality of the air.

\section{I3. PUBLIC MUNICIPAL PARKING}

300 Public parking spaces in vacant lots.

Cars are moved for pedestrian space and vacant lots are used.

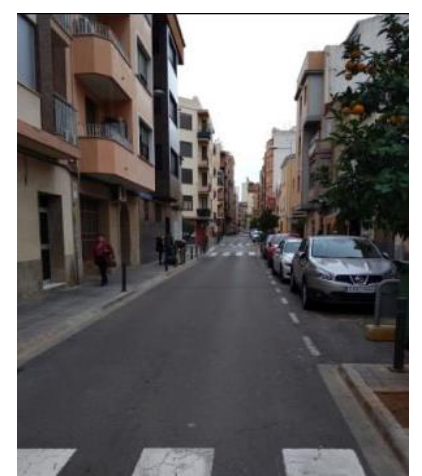
neighborhood diagonally from Ronda Magdalena to Riu Sec Avenue)

Improves student's autonomy to access the School. Pedestrianalization of Segorbe Street will connect the Castalia Stadium to the ARRU03, through Tombatossal Avenue, and to the ARRU04, through Diputación Avenue (it crosses the . 


\section{$\mathrm{LA}_{\mathrm{U} 2}{ }^{01}$ Reorder, recover and condition public spaces and existing green areas.}

\section{Encourage urban appropriation: provide favorable conditions for the use of public spaces}

\section{OBJECTIVES}

Improve the quality of existent leisure public spaces and create new ones.

\section{INTERVENTIONS}

11. San Fernando-Penyagolosa Square improvement

12. New Square

\section{BUDGET}

$256,993.00 €$

\section{MONITORING INDICATORS}

N1.U.02. Green areas

N2.U.04. Abandoned buildings

\section{I1. SAN FERNANDO-PENYAGOLOSA SQUARE IMPROVEMENT}

Square surrounded by San Fernando y

Penyagolosa Streets. Lack of urban equipment and green areas.

Accessibility problems.

Introduce urban furniture such as benches, sport urban facilities appropriate specially for the elderly and the children. This is aimed to improve the physical and psychic well-being of citizens, specially the most vulnerable, and to promote social relations.

\section{NEW SQUARE}

New Square

Create a New Plaza $\mathrm{LA}_{\mathrm{U} 2}{ }^{01-12}$ for children and elderly, connecting the green area that exists behind the nursery and the ground occupied by the unused industrial units shown in the image. It is proposed naming the square considering gender mainstreaming, using the name of a relevant woman.
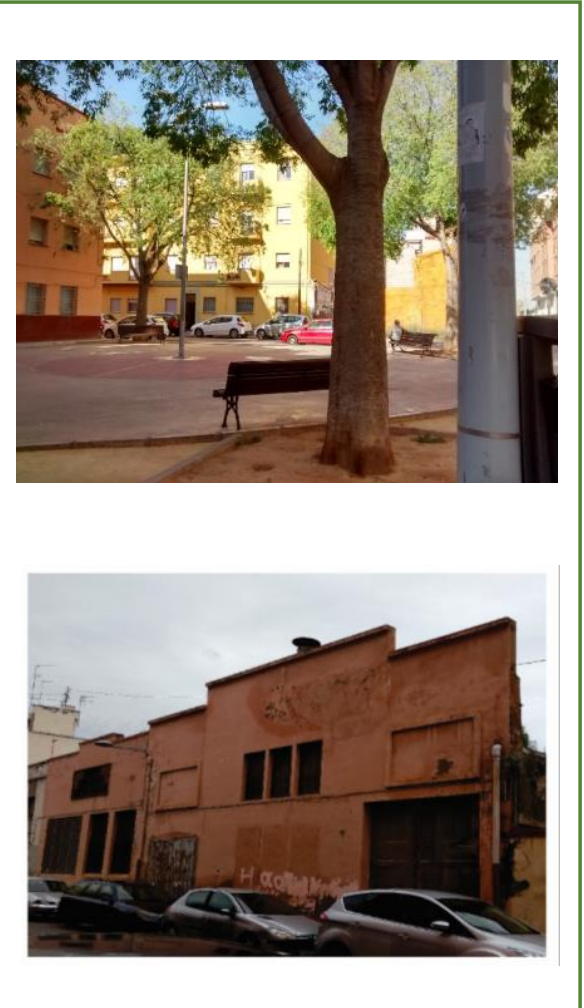


\section{$\mathrm{LA}_{\mathrm{U} 3}{ }^{01}$ Sustainable mobility: improve cyclist network and pedestrian accessibility}

\section{OBJECTIVES}

Improve the mobility and accessibility of public spaces.

\section{INTERVENTIONS}

11. New bicycle lanes

12. Widening of sidewalks

\section{BUDGET}

$106,524.00 €$

\section{MONITORING INDICATORS}

N2.U.03. Proximity to public transportation

N2.U.05. Accessibility in public space

\section{I1. NEW BICYCLE LANES}

New bicycle lane, $2 \mathrm{~m}$ width and independent from sidewalk. It will go from Donoso Cortés Square to Teodoro Izquierdo Square, where currently public bicycle sharing system is available. It will cross the ARRU diagonally, along Cronista Rocafort ad Teniente Monzonís Streets.

\section{WIDENING OF PAVEMENTS}

Remodeling of pavements in bad maintenance state (see plans). Widening of sidewalks under $1.80 \mathrm{~m}$. Fulfilment of accessibility requirements according to updated regulations (access ramps, appropriate pavements adapted to disabled such as podotactile pavement...).
Reduces car traffic, improves the quality of the air and the health of the users.
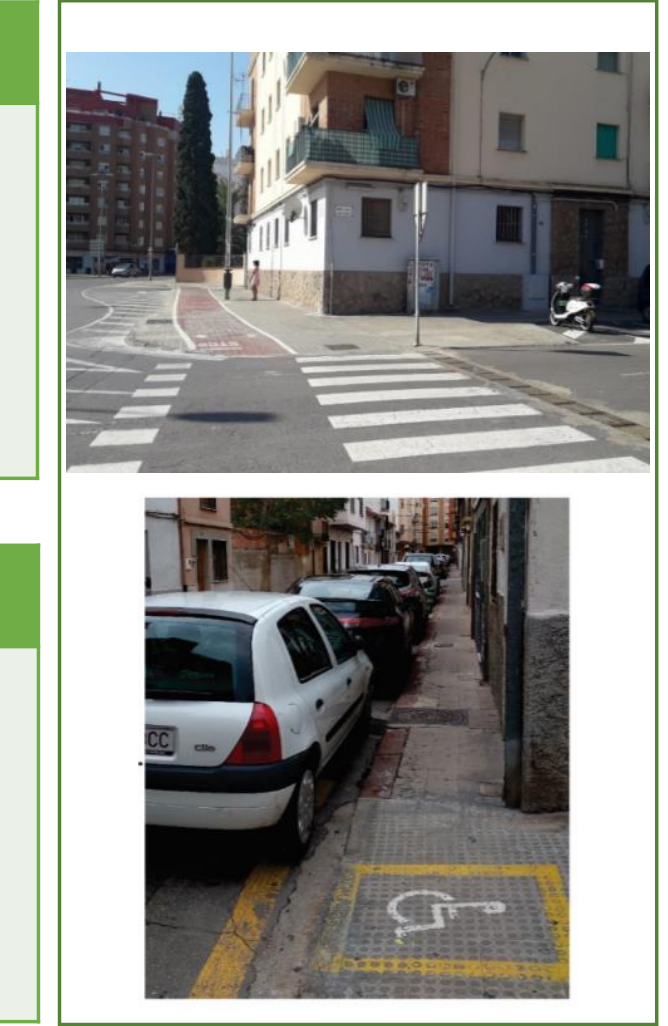

Improves the

movements of pedestrians and guarantees universal accessibility. 


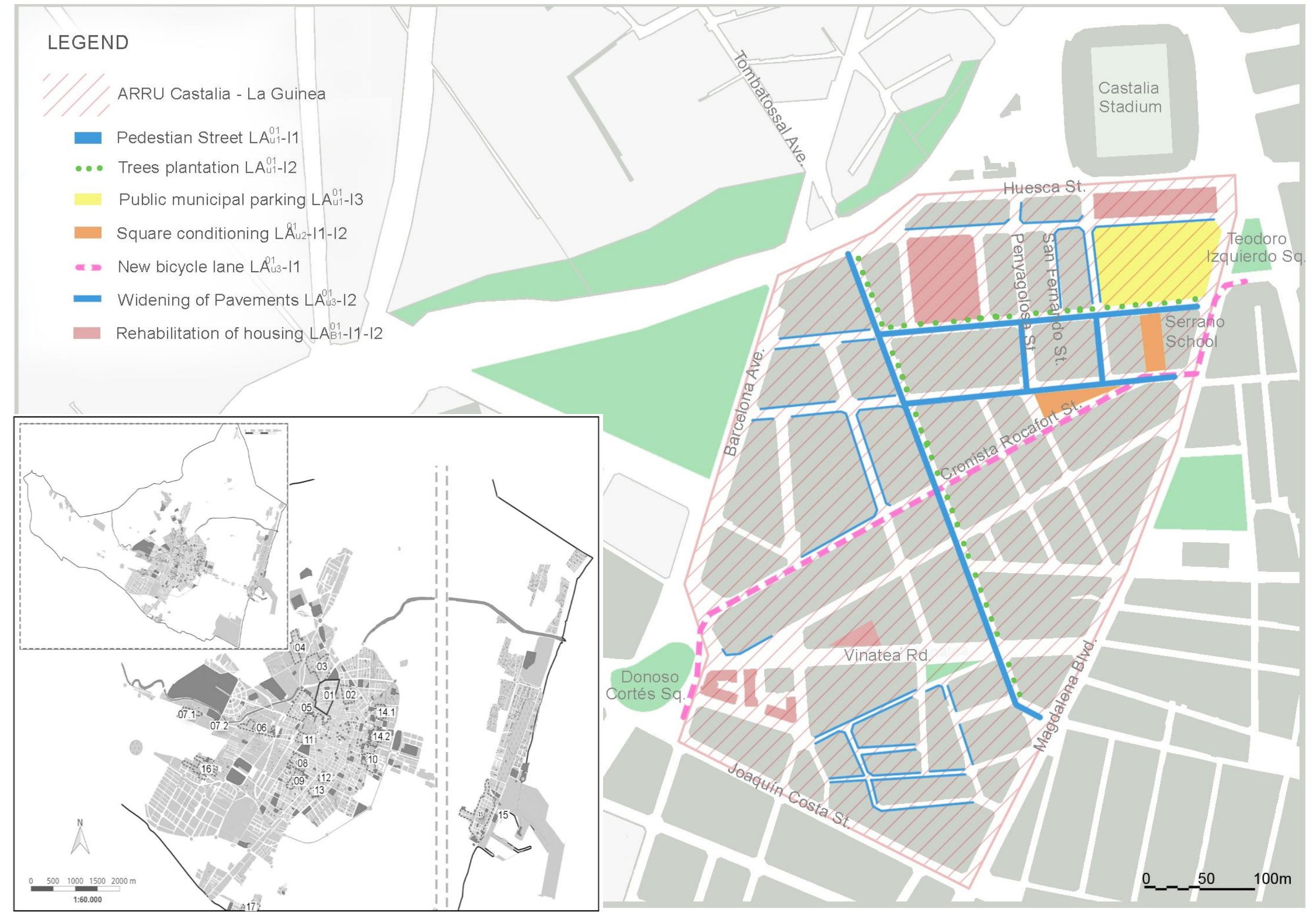




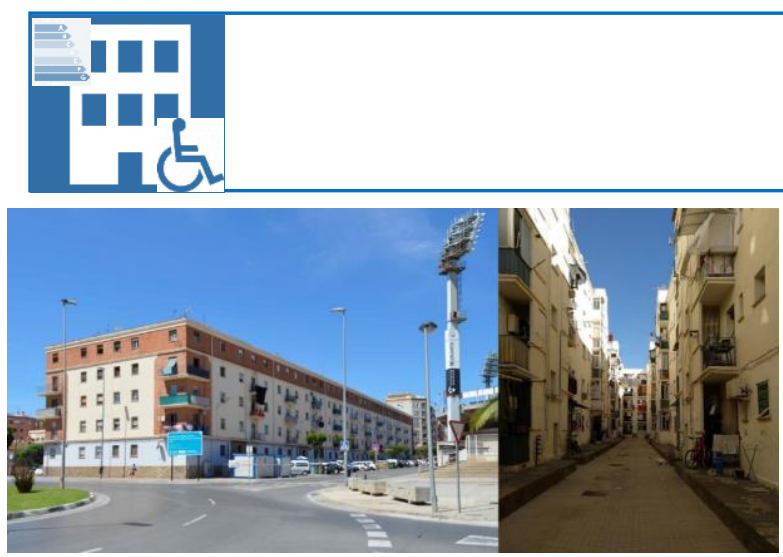

\section{General information of the case study building}

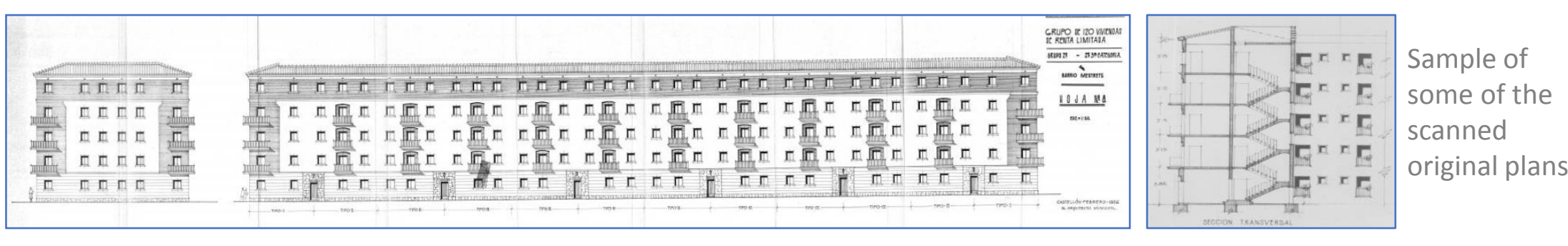

- Block built in 1959

- 12 buildings around a lightwell

- 5 floors

- 10 dwellings per building
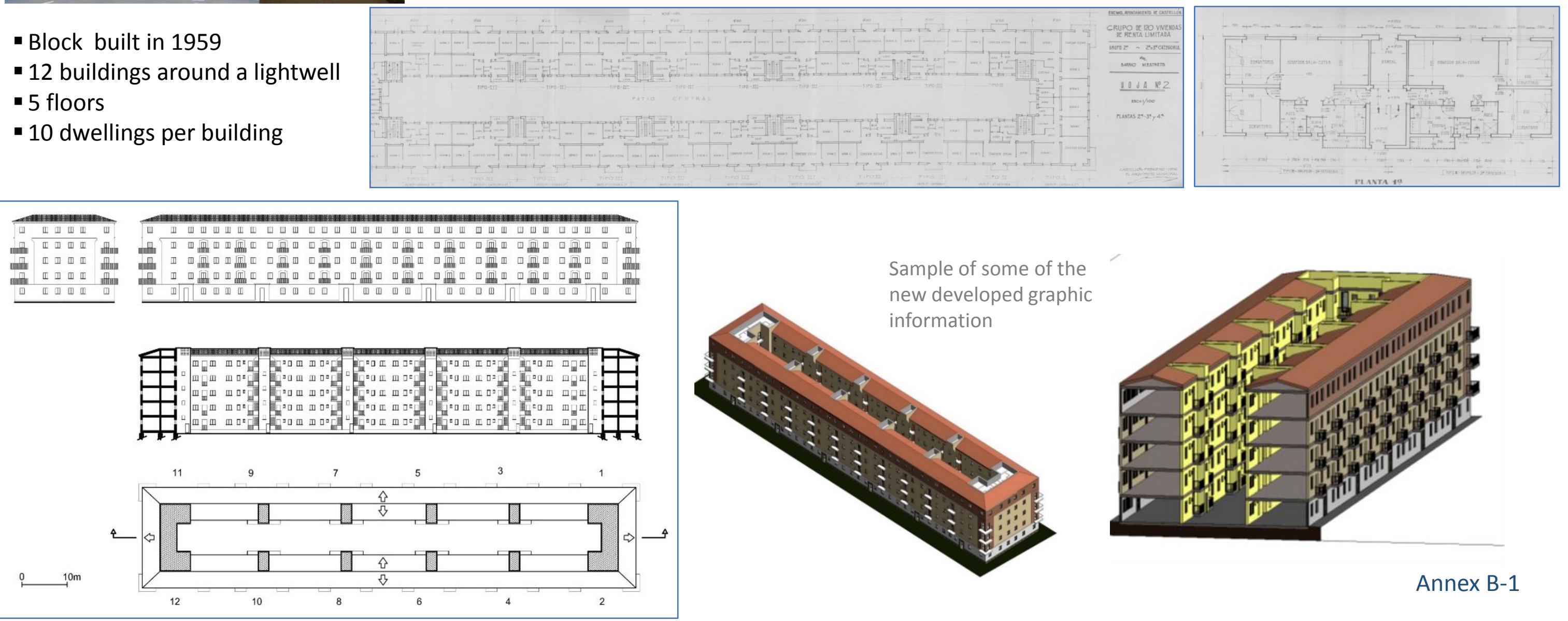


General information of the case study building

\begin{tabular}{|c|c|}
\hline $\begin{array}{l}\text { Thermal } \\
\text { envelope }\end{array}$ & Constructive solution \\
\hline Façade 1 & $\begin{array}{l}\text { Bearing wall formed by double leaf brick: exterior masonry wall of ceramic } \\
\text { solid brick of } 1 \text { foot-thick with cement mortar joints + inner skin of hollow } \\
\text { ceramic brick, } 4 \text {-cm thick, with cement mortar joints + plastering. Exposed } \\
\text { area: } \mathrm{N} 93.41 \mathrm{~m}^{2} ; \mathrm{W} 78.93 \mathrm{~m}^{2} \text {. Transmittance } 1.44 \mathrm{~W} / \mathrm{m}^{2} \mathrm{~K} \text {. }\end{array}$ \\
\hline Façade 2 & $\begin{array}{l}\text { Bearing wall formed by double leaf brick: continuous outer coating with } \\
\text { cement mortar + exterior masonry wall of ceramic solid brick of } 1 \text { foot-thick } \\
\text { with cement mortar joints + inner skin of hollow ceramic brick } 4 \mathrm{~cm} \text {-thick } \\
\text { with cement mortar joints + plastering. Exposed area: } \mathrm{N} 190.64 \mathrm{~m}^{2} ; \mathrm{W} \\
100.63 \mathrm{~m}^{2} \text {; E } 57.84 \mathrm{~m}^{2} ; \mathrm{S} 169.51 \mathrm{~m}^{2} \text {. Transmittance } 1.29 \mathrm{~W} / \mathrm{m}^{2} \mathrm{~K} \text {. }\end{array}$ \\
\hline Windows & $\begin{array}{l}\text { Wood carpentry with single glazing. Transmittance carpentry: } 2.20 \mathrm{~W} / \mathrm{m}^{2} \mathrm{~K} \\
\text { and glazing } 5.50 \mathrm{~W} / \mathrm{m}^{2} \mathrm{~K} \text {. }\end{array}$ \\
\hline Roof 1 & $\begin{array}{l}\text { Flat roof ventilated, trafficable: Finishing ceramic tiles + mortar layer } 5 \mathrm{~cm}+ \\
\text { bituminous sheet + ventilated air chamber + reinforced concrete one-way } \\
\text { slab } 30 \mathrm{~cm} \text {, ceramic hollow plot + plastering. Exposed area: } 38.83 \mathrm{~m}^{2} \text {. } \\
\text { Transmittance } 1.37 \mathrm{~W} / \mathrm{m}^{2} \mathrm{~K} \text {. }\end{array}$ \\
\hline Roof 2 & $\begin{array}{l}\text { Gable sloping roof ventilated } 160 \text { : finishing ceramic gables + mortar layer + } \\
\text { ceramic tiles for roof slope + ventilated air chamber + reinforced concrete } \\
\text { one-way slab } 30 \mathrm{~cm} \text {, ceramic hollow plot + plastering. Exposed area: } 116.03 \\
\mathrm{~m}^{2} \text {. Transmittance } 1.05 \mathrm{~W} / \mathrm{m}^{2} \mathrm{~K} \text {. }\end{array}$ \\
\hline
\end{tabular}

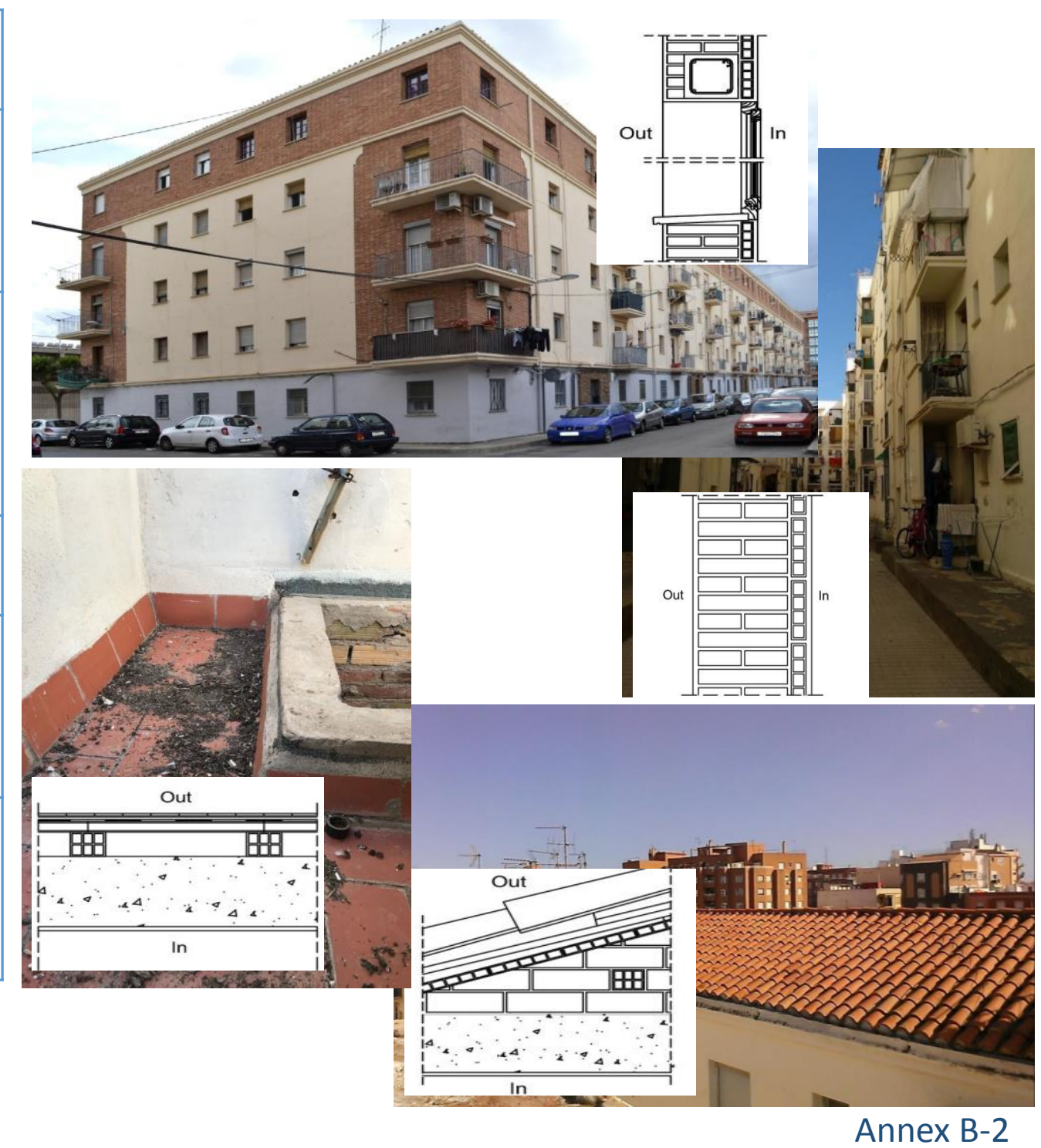


Q1. Energy performance improvement

\begin{tabular}{|c|c|c|c|}
\hline \multicolumn{3}{|c|}{ DIAGNOSIS } & \\
\hline \multicolumn{4}{|l|}{ Indicador $\mathrm{kgCO} / \mathrm{m} 2$} \\
\hline$<3.6 \quad$ A & $2 \cos x$ & & $=\square$ \\
\hline$<6.8$ & & Out & \\
\hline$<11.5$ & & & \\
\hline$<18.5$ & & & \\
\hline$<41.5$ & E & & $=\square \mathrm{B}$ \\
\hline$<46.9$ & & & \\
\hline$>=46.9$ & & & \\
\hline & Current state & Refurbished & Saving \% \\
\hline Heating demand $\mathrm{kWh} / \mathrm{m}^{2}$ & $64.5 \mathrm{~F}$ & $17.5 \mathrm{C}$ & 72.8 \\
\hline Cooling demand $\mathrm{kWh} / \mathrm{m}^{2}$ & $17.8 \mathrm{D}$ & 14.7D & 17.3 \\
\hline Heating emissions & 16.0E & $4.3 \mathrm{C}$ & 72.8 \\
\hline Cooling emissions & $5.1 \mathrm{D}$ & $4.2 \mathrm{D}$ & 17.3 \\
\hline DHW emissions & $8.4 G$ & $6.7 \mathrm{G}$ & 19.9 \\
\hline Global emissions & $29.5 \mathrm{E}$ & 15.3D & 48.1 \\
\hline
\end{tabular}

\section{PROPOSAL}

Façades: External Insulation System. Windows: Double glazing windows.

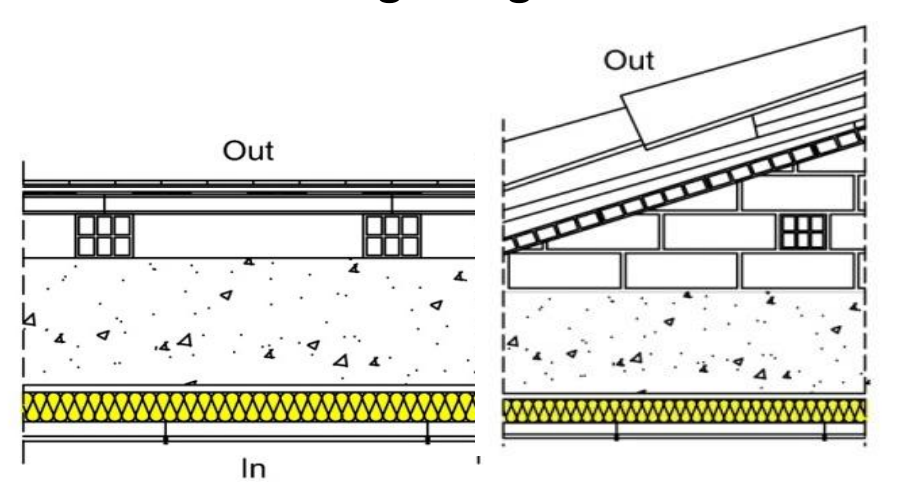

Roofs: inner solution involving mineral wool and finishing plaster board.

Facilities: from electrical boilers to condensed heater with natural gas.

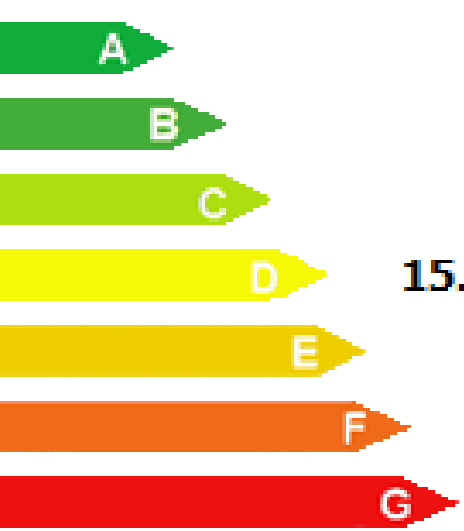

Budget: $€ 10,519.56 / d$ welling

Total: $€ 1,262,347.20$

*Detail of análisis in Ruá et al, 2018 


\section{Q2. Conservation improvement}

\section{DIAGNOSIS}

PROPOSAL

Structural system: no cracks or bending are observed in the structural elements.

Façades: There is a lack of maintenance. Part of the painting in façades has become chipped. The aesthetic of façade needs to be updated.

Windows: Lack of air tightness. There is a lack of maintenance.

Roofs: There is a lack of maintenance.
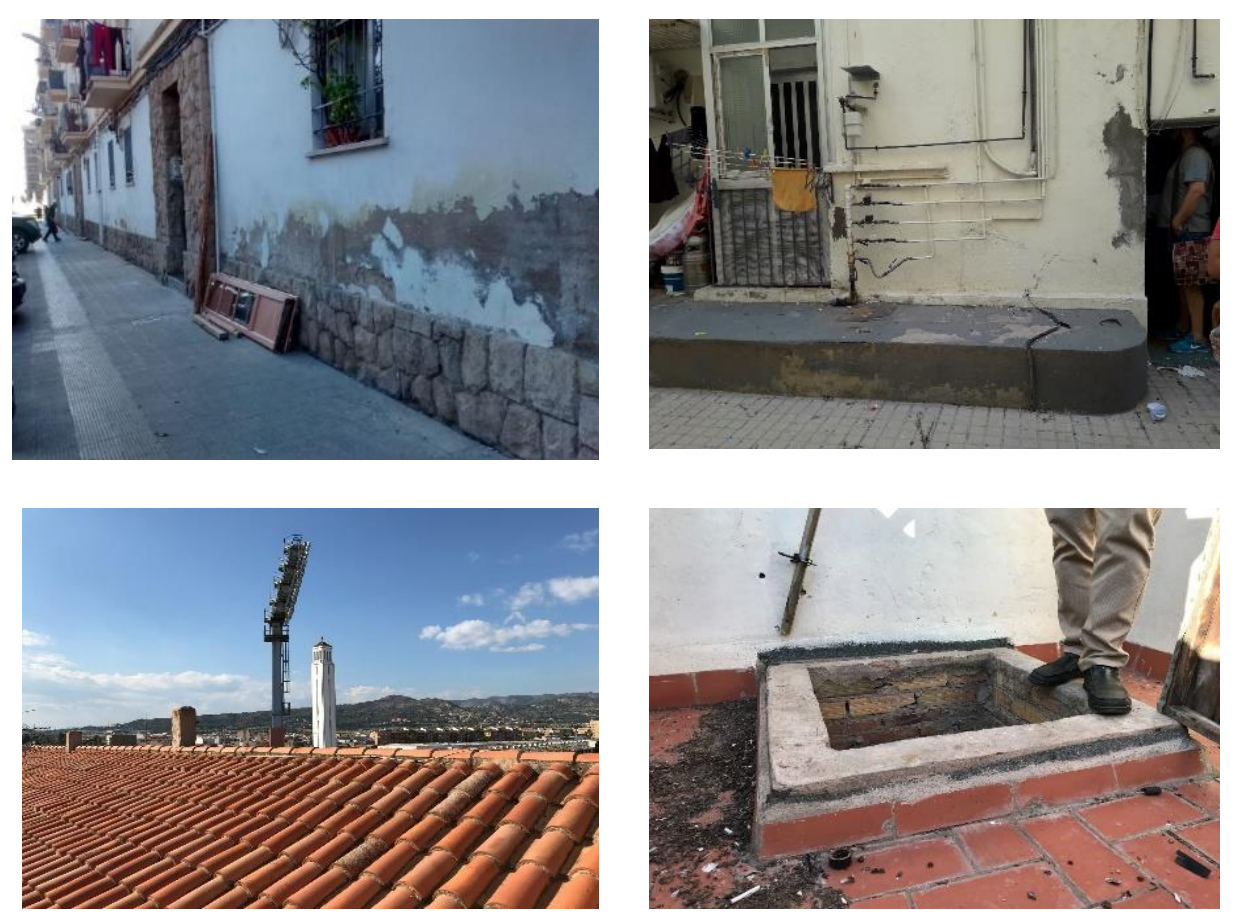

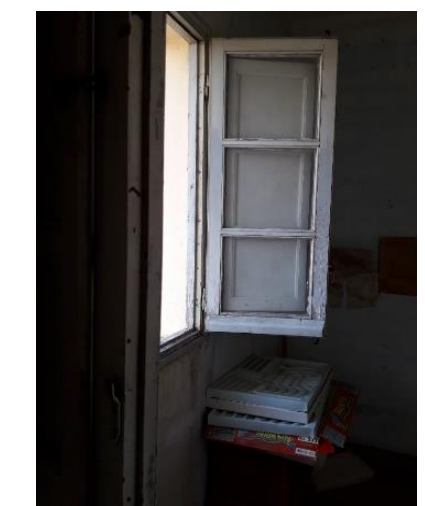

Façades: The ETICS will improve aesthetically the façades.

Windows: The change of windows proposed for energy performance will solve the tightness problem.

Roofs: maintenance and cleaning tasks are proposed.

\section{Budget: $€ 21.85 /$ dwelling \\ *Total: $€ 2,622.00$}

*Including: Roof maintenance: Labour cost: 13,11 €/h, 200 hours, source: 2017 prices, retrieved from data base Valencian Institute of Building IVE, available at

http://www.five.es/productos/herramientas-online/visualizador-2017/, last accesed 21st July 2020). 


\begin{tabular}{|l|l|}
\hline DIAGNOSIS & Q3. Accessibility improvement \\
\hline
\end{tabular}
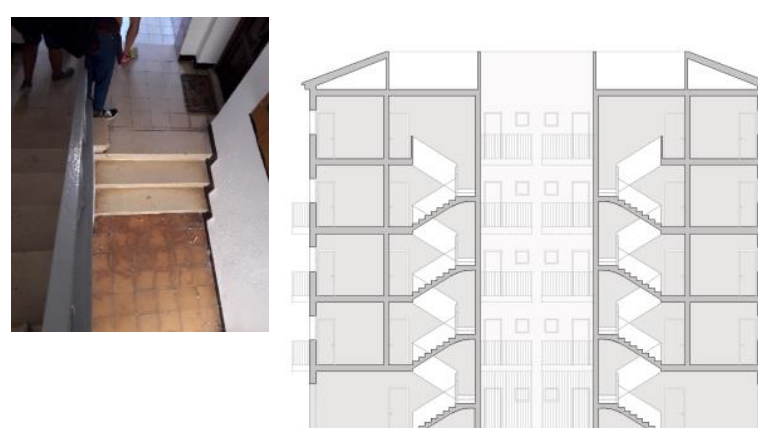

Only staircases.

Step width +0.75 meters . Height difference between ground level and entrance halls levels is solved with steps.
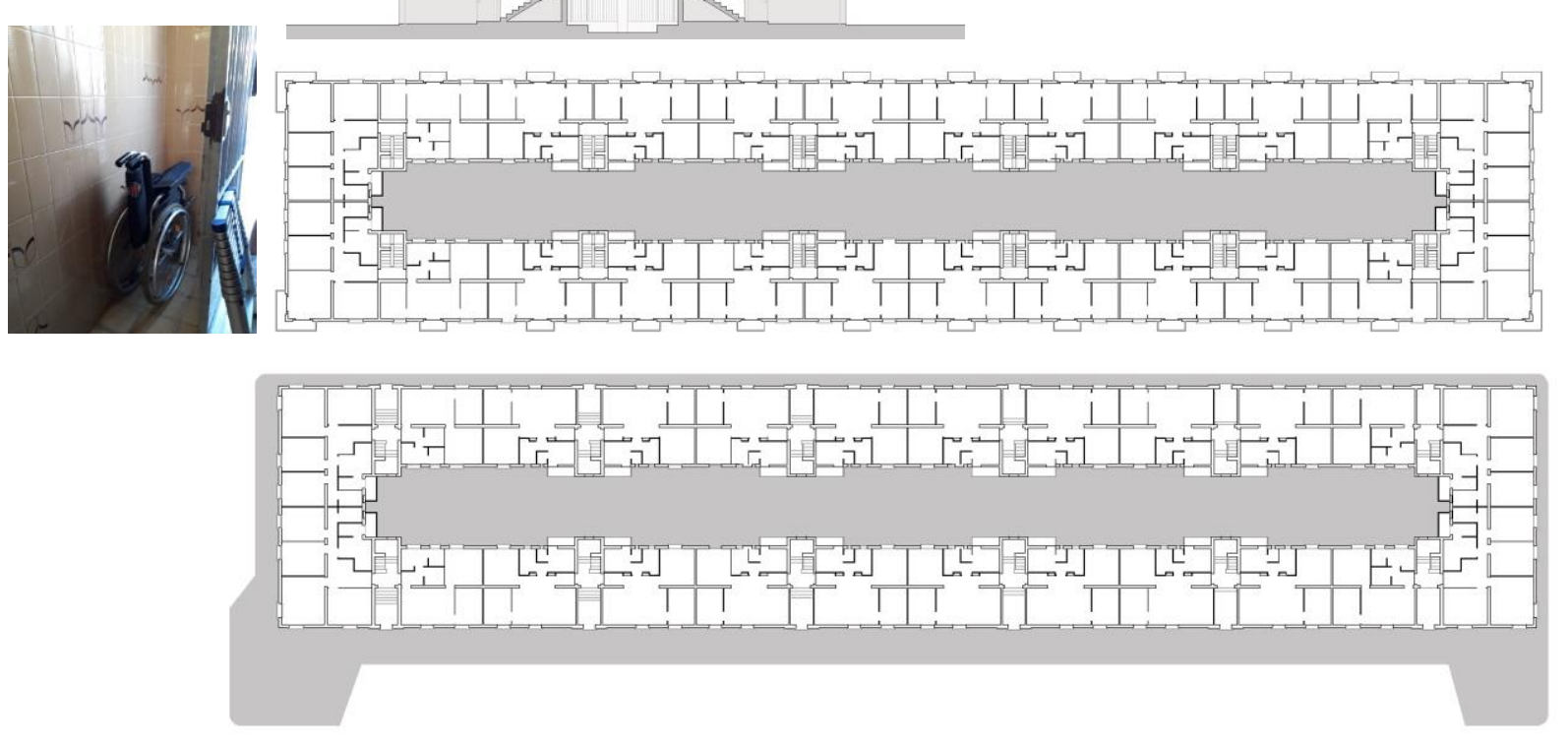

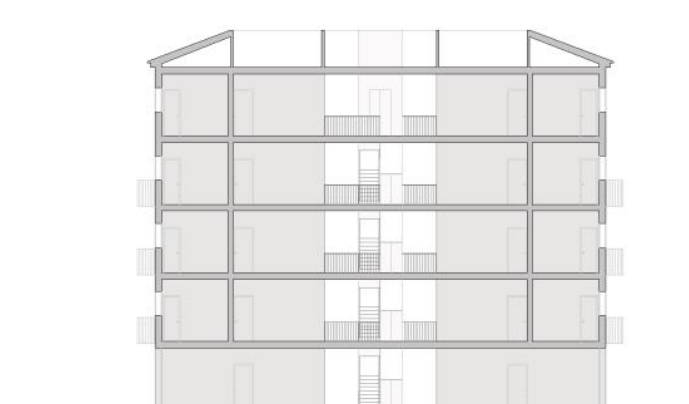

Staircases + lifts.

Step width +1.00 meter. Height difference between ground level and two entrance halls levels is solved with a slope ramp $<10 \%$.
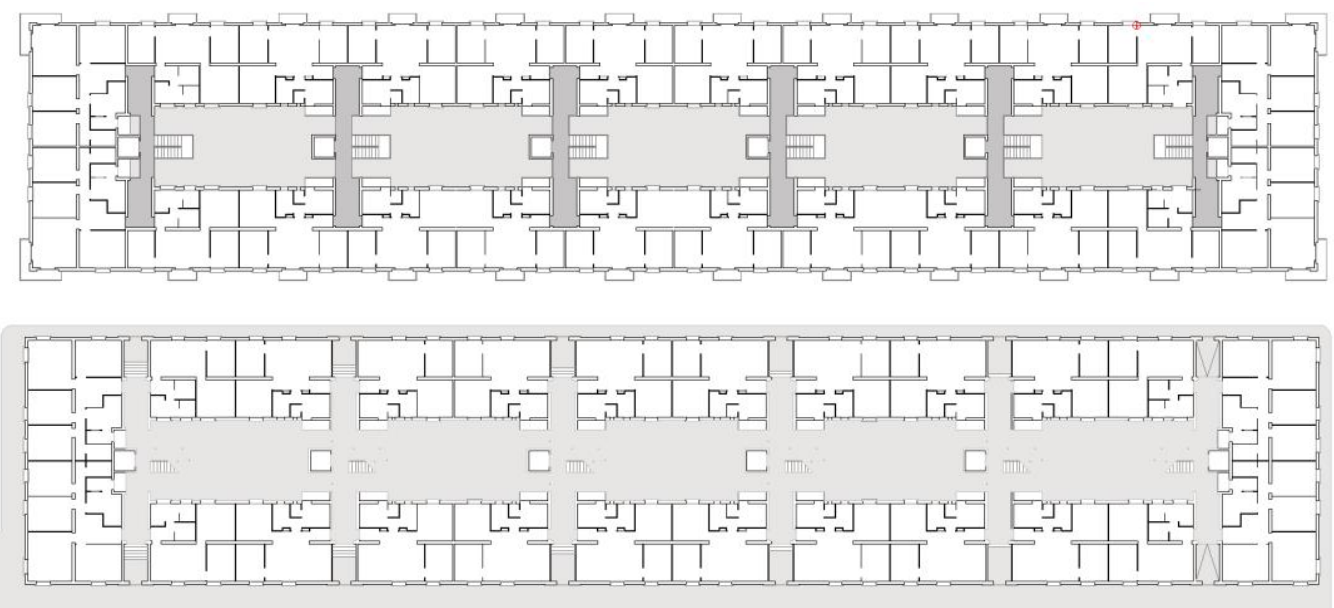

Budget: €9,724.12/dwelling Total: $€ 1,166,894.40$ 


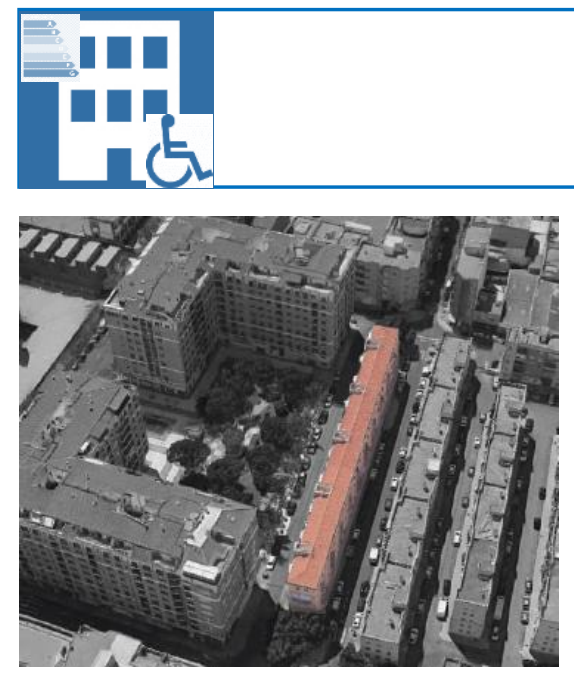

- Block built in 1959

- 5 buildings

- 5 floors

- 10 dwellings per building

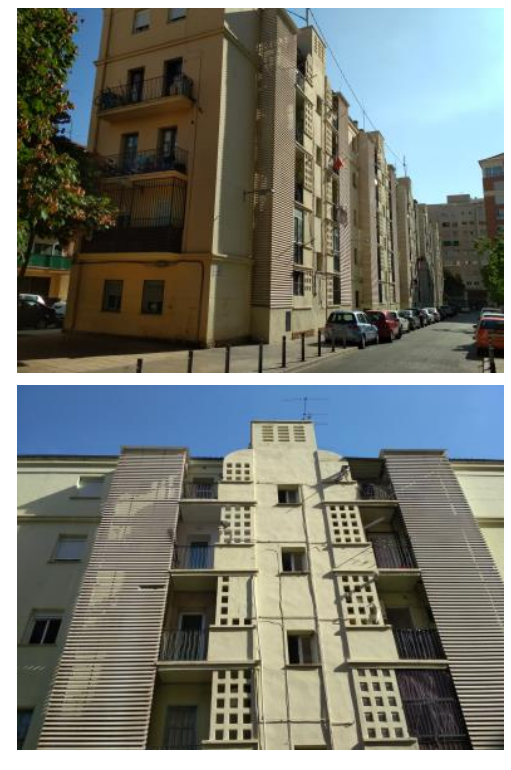

General information of the comparative building in ARRU10
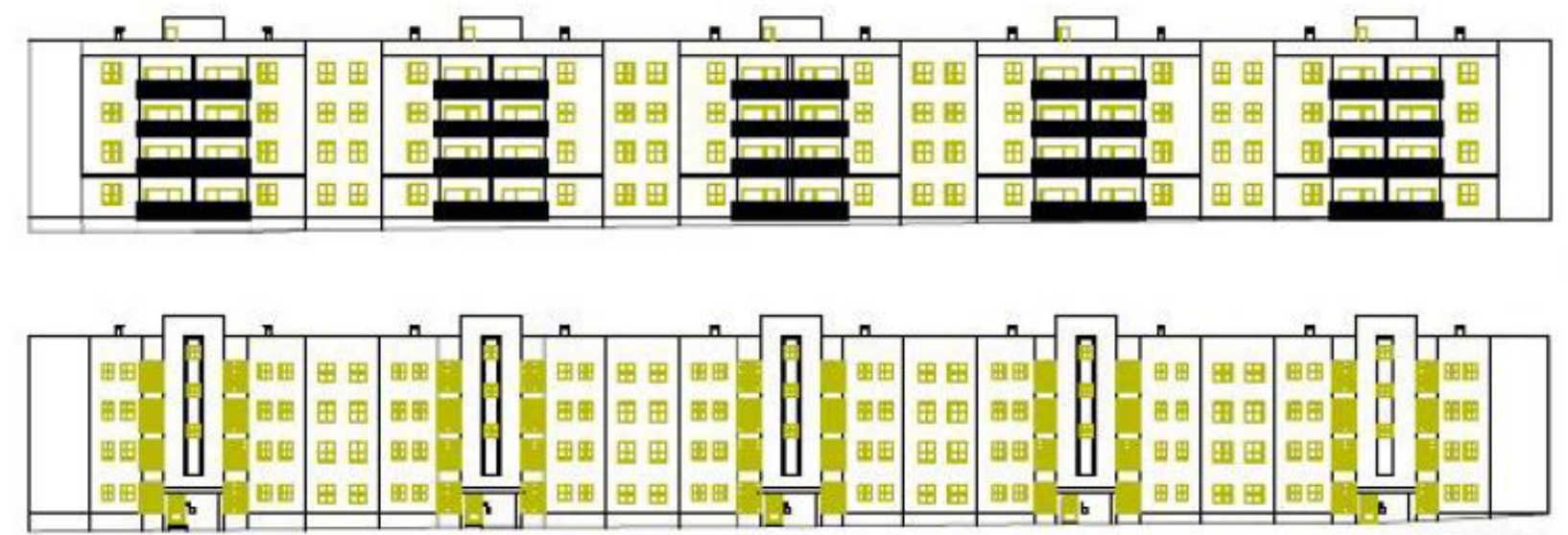
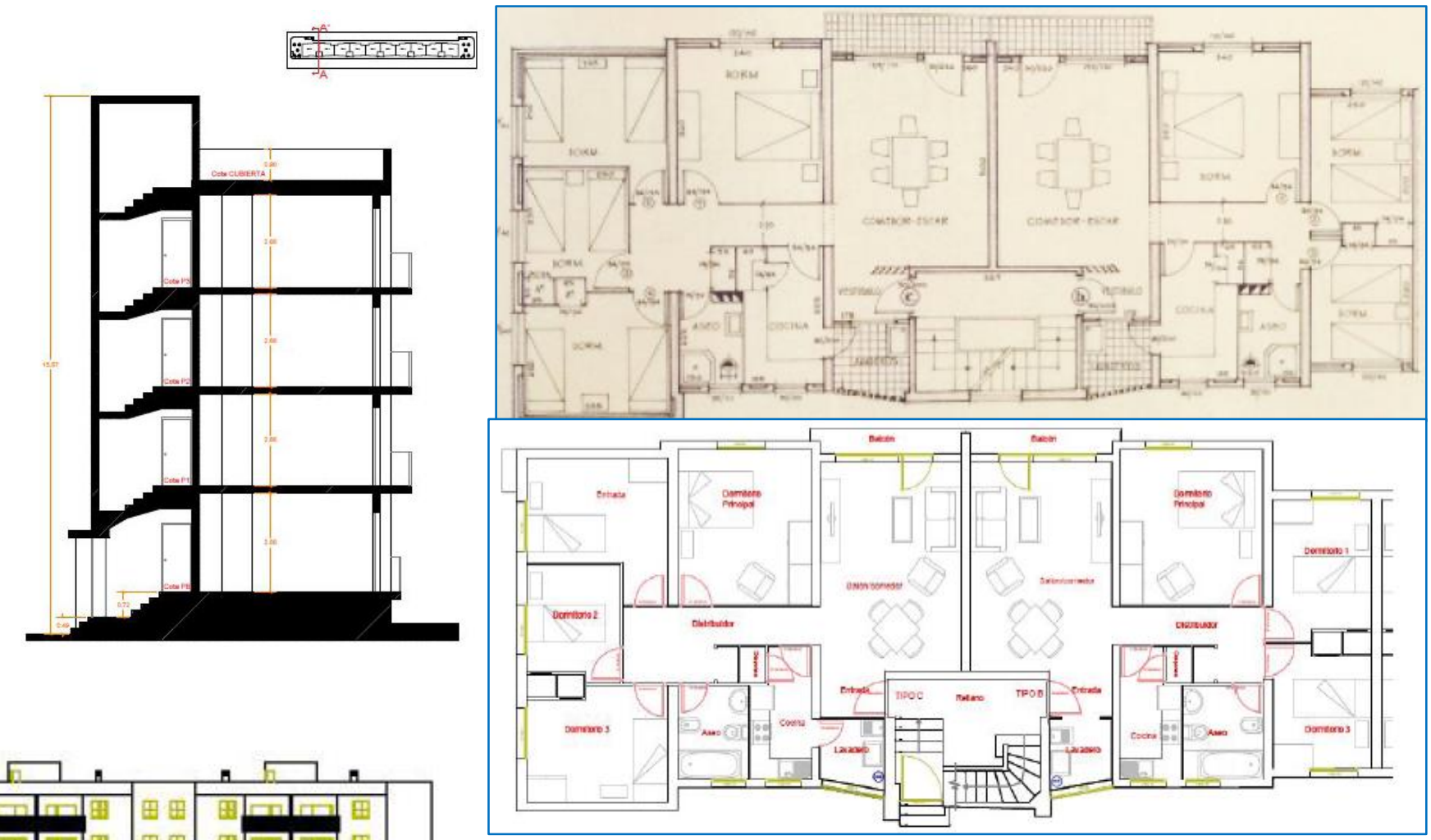

Sample of original and new plans. Ground floor of building 


\begin{tabular}{|c|c|}
\hline $\begin{array}{l}\text { Thermal } \\
\text { envelope }\end{array}$ & Constructive solution \\
\hline Façade 1 & $\begin{array}{l}\text { Bearing wall formed by double leaf brick: exterior masonry wall of } \\
\text { ceramic solid brick of } 1 \text { foot-thick with cement mortar joints + inner skin } \\
\text { of hollow ceramic brick, 4-cm thick, with cement mortar joints + } \\
\text { plastering. Exposed area: N } 93.41 \mathrm{~m}^{2} ; \mathrm{W} 78.93 \mathrm{~m}^{2} \text {. Transmittance } 1.44 \\
\mathrm{~W} / \mathrm{m}^{2} \mathrm{~K} \text {. }\end{array}$ \\
\hline Façade 2 & $\begin{array}{l}\text { Bearing wall formed by double leaf brick: continuous outer coating with } \\
\text { cement mortar + exterior masonry wall of ceramic solid brick of } 1 \text { foot- } \\
\text { thick with cement mortar joints + inner skin of hollow ceramic brick } 4 \\
\mathrm{~cm} \text {-thick with cement mortar joints + plastering. Exposed area: N } 190.64 \\
\mathrm{~m}^{2} ; \mathrm{W} 100.63 \mathrm{~m}^{2} \text {; E } 57.84 \mathrm{~m}^{2} \text {; S } 169.51 \mathrm{~m}^{2} \text {. Transmittance } 1.29 \mathrm{~W} / \mathrm{m}^{2} \mathrm{~K} \text {. }\end{array}$ \\
\hline Windows & $\begin{array}{l}\text { Wood carpentry with single glazing. Transmittance carpentry: } 2.20 \\
\mathrm{~W} / \mathrm{m}^{2} \mathrm{~K} \text { and glazing } 5.50 \mathrm{~W} / \mathrm{m}^{2} \mathrm{~K} \text {. }\end{array}$ \\
\hline Roof 1 & $\begin{array}{l}\text { Flat roof ventilated, trafficable: Finishing ceramic tiles + mortar layer } 5 \mathrm{~cm} \\
+ \text { bituminous sheet + ventilated air chamber + reinforced concrete one- } \\
\text { way slab } 30 \mathrm{~cm} \text {, ceramic hollow plot + plastering. Exposed area: } 38.83 \\
\mathrm{~m}^{2} \text {. Transmittance } 1.37 \mathrm{~W} / \mathrm{m}^{2} \mathrm{~K} \text {. }\end{array}$ \\
\hline Roof 2 & $\begin{array}{l}\text { Gable sloping roof ventilated } 160 \text { : finishing ceramic gables + mortar layer } \\
+ \text { ceramic tiles for roof slope + ventilated air chamber + reinforced } \\
\text { concrete one-way slab } 30 \mathrm{~cm} \text {, ceramic hollow plot + plastering. Exposed } \\
\text { area: } 116.03 \mathrm{~m}^{2} \text {. Transmittance } 1.05 \mathrm{~W} / \mathrm{m}^{2} \mathrm{~K} \text {. }\end{array}$ \\
\hline
\end{tabular}

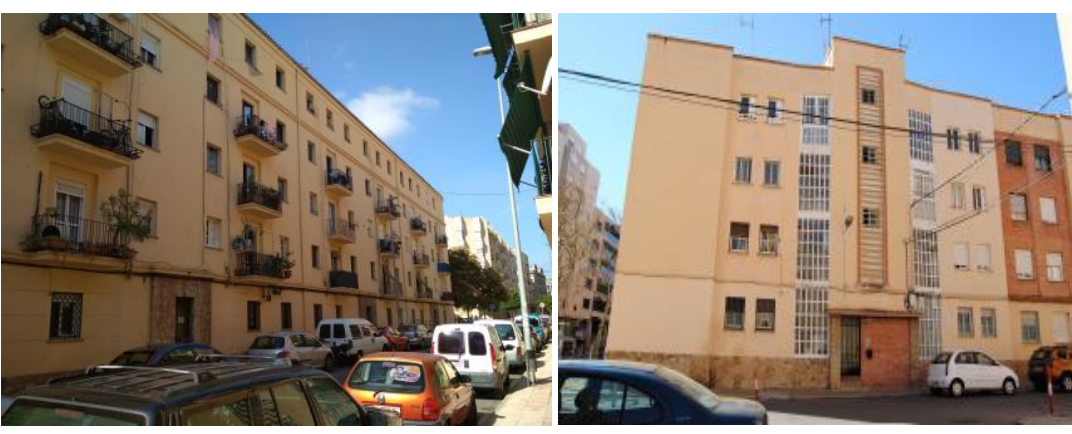

Out

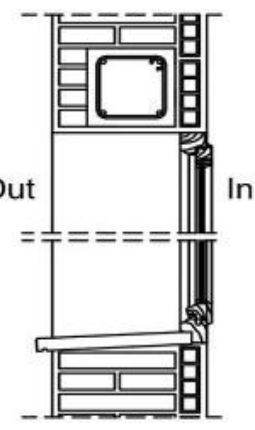

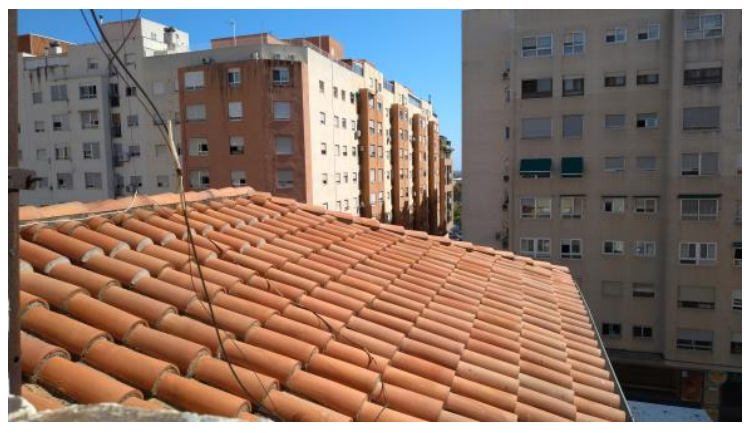
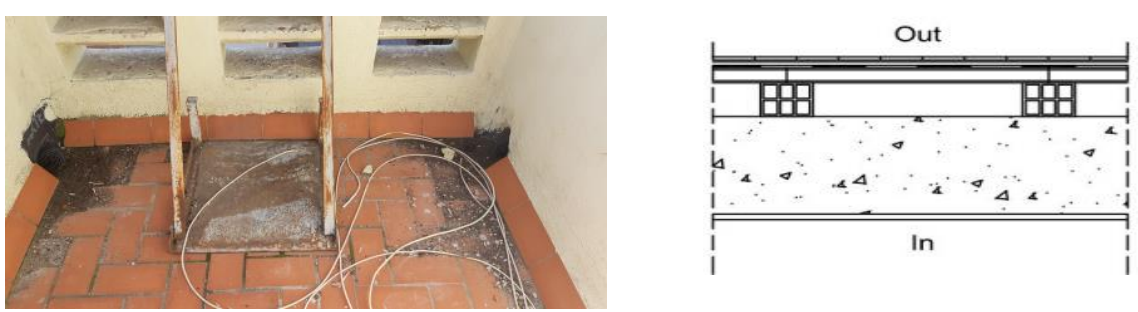


\section{Q1. Energy performance improvement}

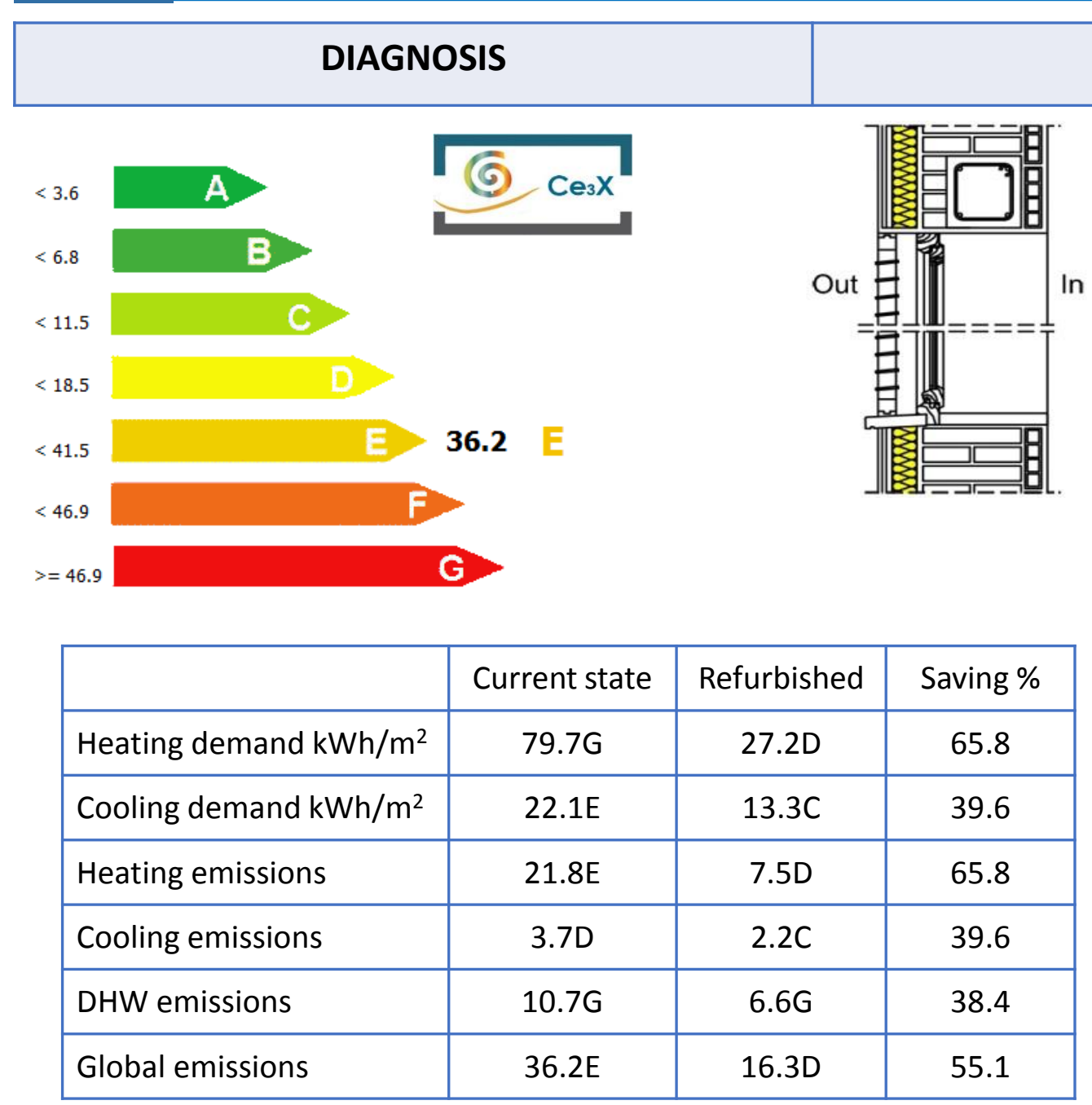

\section{PROPOSAL}

Façades: External Insulation System. Windows: Double glazing windows.

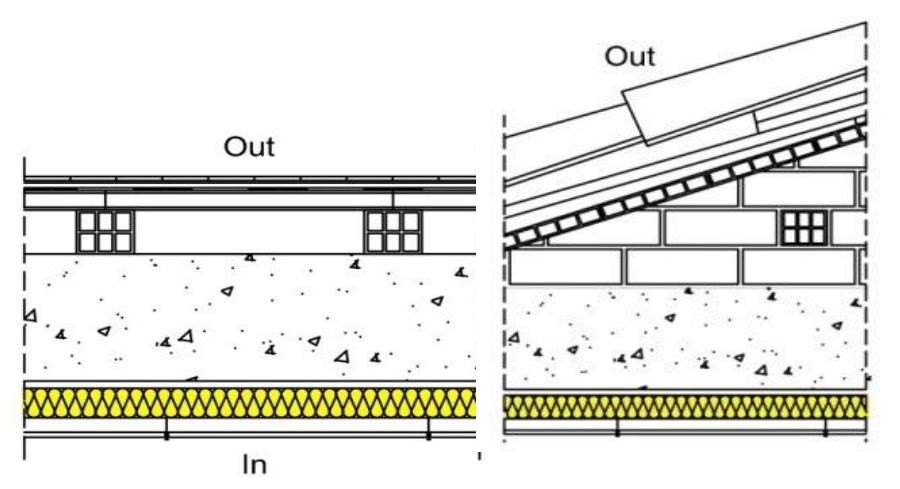

Roofs: inner solution involving mineral wool and finishing plaster board.

Facilities: from electrical boilers to condensed heater with natural gas.

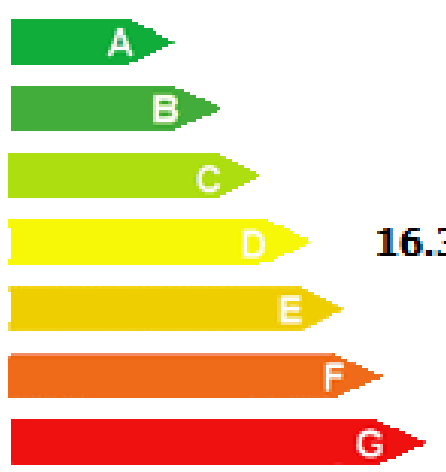

Budget: $€ 13,329.38 / d w e l l i n g$ Total: €666,469.38 


\section{Q2. Conservation improvement}

\section{DIAGNOSIS}

PROPOSAL

Structural system: no cracks or bending are observed in the structural elements.

Façades: There is a lack of maintenance. Part of the painting in façades has become chipped, due to damp by rising dump. The aesthetic of façade needs to be updated.

Windows: Lack of air tightness. There is a lack of maintenance.

Roofs: There is a lack of maintenance.

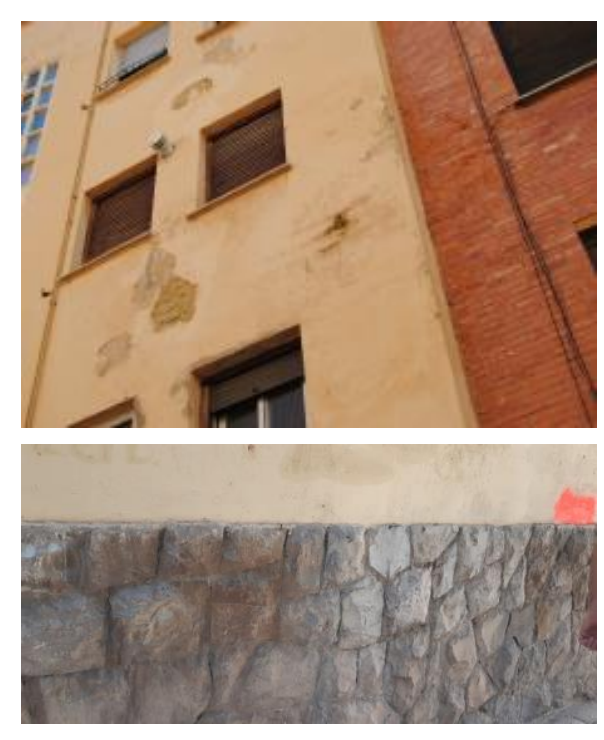

Façades: Damp problem is solved using passive electro-osmosis system, before the ETICS for improvement of energy performance is installed. The ETICS will improve aesthetically the façades.

Windows: The change of windows proposed for energy performance will solve the tightness problem.

Roofs: maintenance and cleaning tasks are proposed.

\section{Budget: €690.20/dwelling \\ Total: $€ 34,509.80$}

Includes:

1. Passive electro-osmosis in façades $(129,59 € / \mathrm{m} ; 110 \mathrm{~m}$ North façade + $110 \mathrm{~m}$ South façade. 28,509.80 $€$ and 570,19 $€$ /dwelling, source: 2017 prices, retrieved from data base Valencian Institute of Building IVE, available at http://www.five.es/productos/herramientas-online/visualizador-2017/, code RNHB.3b-m, last accesed 21st July 2020). 2. Roof maintenance: Labour cost: 13,11 $€ / h, 150$ hours, source: 2017 prices $1,966.50 €$ and $39.33 € /$ dwelling. 


\section{DIAGNOSIS}

PROPOSAL

- Only staircases. No lift

- Step width + 0.82 meters.

- Stairs to access the building from the street level, and stairs to access to the ground floor dwellings.
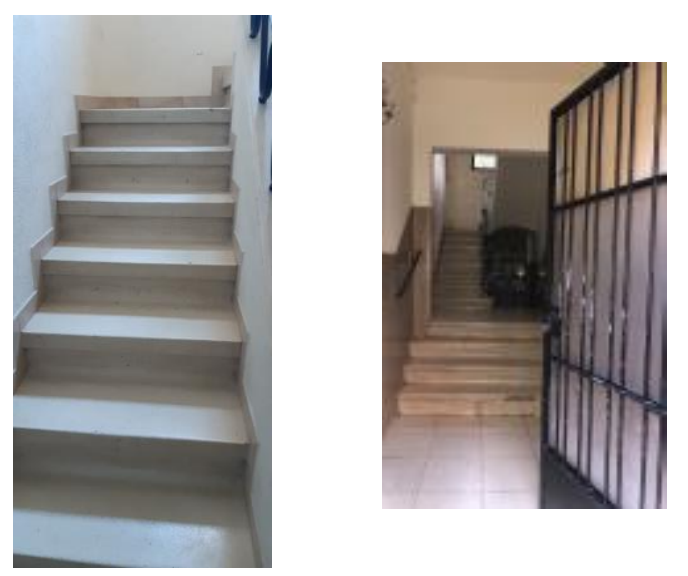

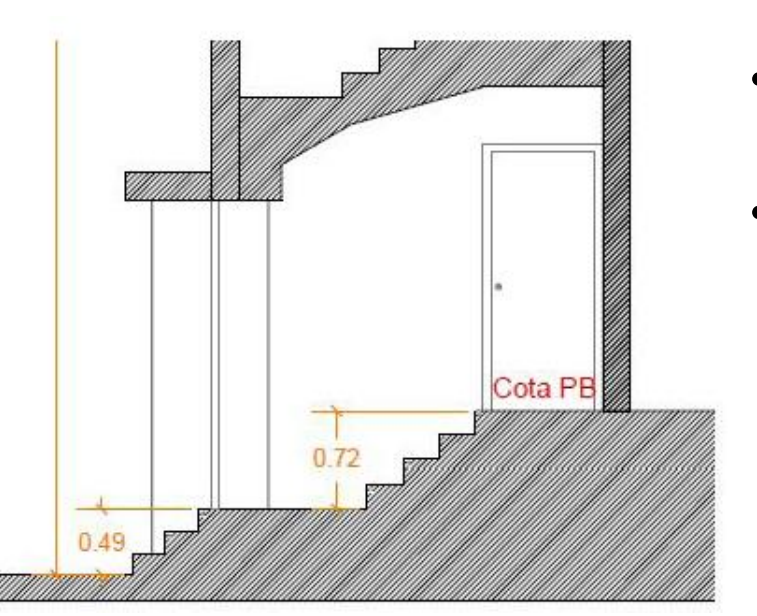

- Ramps for the disabled to access to the building from the street level.

- Stairlifts to access to ground level dwellings.

- Staircases + lifts attached to North façade.

- Step width +1.00 meter.
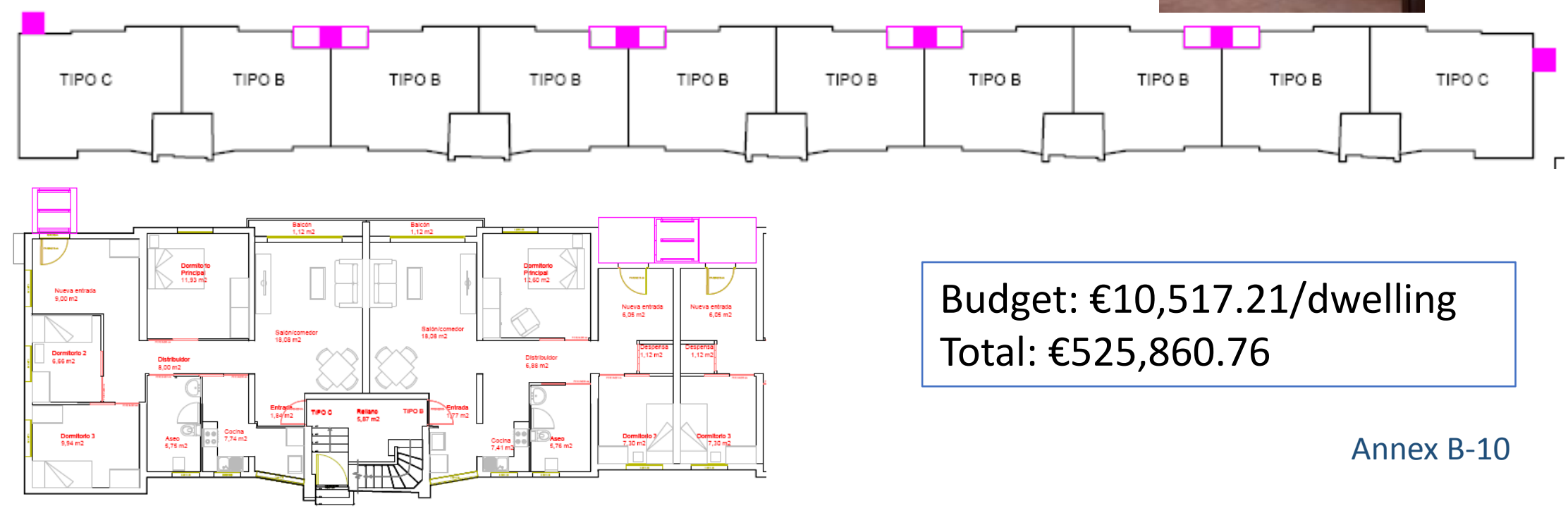

Budget: $€ 10,517.21 / d$ welling Total: $€ 525,860.76$ 